\title{
Güven Teorisi Kapsamında Çevrimiçi Fayda ve Riskin Web Sitesinin Değerine Etkisinde Siteye Güvenin Aracı, Riskin Düzenleyici Etkileri
}

\author{
The Mediating of Trust in the Website in the Effect of Online Benefit and \\ Risk on the Value of the Website under the Theory of Trust, Moderating \\ Effects of Risk
}

\section{Öz}

Günümüzde hazır giyim ürünü satan web siteleri; teknolojik değişim ve gelişime bağh olarak müşterilerine çeşitli alternatifler sunup ürünlerini pazarlamaktadırlar. Tüketicilerin web sitelerine yönelik çevrimiçi alışveriş davranışlarında, fayda, risk, güven ve değer kavramlarının incelenmesi önemli sonuçlar ortaya koyabilir. Bu açıdan araştırma güven teorisi kapsamında tüketicilerin web sitelerinden algıladıkları çevrimiçi faydalar ve risklerin, siteye olan güven ve sitenin tüketici gözündeki değerini etkileme düzeyleri araştırmanın ana amacını oluşturmaktadır. Bu amaç doğrultusunda araştırmada üç model oluşturulmuştur. Birinci modelde faydanın güven üzerindeki etkisinde riskin düzenleyici etkisi araştırılmıştır. İkinci model fayda ve risk açısından sitenin tüketici gözündeki değeri üzerindeki etkisi incelenmiştir. Üçüncü model ise fayda ve riskin sitenin değeri üzerindeki etkisinde güvenin aracı etkileri araştırılmıştır. Araştırma sonucunda, tüketicilerin web sitelerinden algıladıkları çevrimiçi faydanın siteye olan güveni üzerindeki etkisinde çevrimiçi risk düzenleyici etkisinin olduğu tespit edilmiştir. Çevrimiçi fayda, siteye olan güveni pozitif ve anlaml, çevrimiçi risk siteye olan güveni negatif ve anlaml bir şekilde etkilemiştir. Bunun yanında tüketicilerin çevrimiçi risk algılar sitenin değerini negatif ve anlaml olarak etkilemiştir. Çeorimiçi risklerin sitenin değeri üzerindeki etkisinde siteye olan güven tam aracı etkiye sahip olmuştur. Ayrıca, tüketicilerin çeorimiçi fayda algıları sitenin değerini pozitif ve anlamlı etkisinin olduğu saptamıştır. Çevrimiçi faydanın sitenin değeri üzerindeki etkisinde siteye güvenin kısmi aracı etkisi bulunmuştur. Araştırmada siteye olan güven ise, tüketici açısından sitenin değerini pozitif ve anlaml olarak etkilemiştir.

\author{
İbrahim Durmuş \\ Öğr. Gör. Dr., Gümüşhane Üniversitesi, \\ ibrahimdurmus@gumushane.edu.tr, \\ Orcid No: https://orcid.org/0000-0002- \\ 3872-2258
}

\section{Emel Yildız}

Doç. Dr., Gümüşhane Üniversitesi, emelyildiz@gumushane.edu.tr, Orcid No: https://orcid.org/0000-00017190-593X

Article Type/Makale Türü

Research Article / Araştırma Makalesi

\begin{abstract}
Anahtar Kelimeler
Site Değeri, Çevrimiçi Faydalar, Çeorimiçi Riskler, Siteye Güven.
Keywords
Site Value, Online Benefits, Online Risks, Trust Site.
\end{abstract}

JEL Codes: $M 30, M 31, M 37$

Submitted: 19 / 08 / 2021

Accepted: $03 / 11 / 2021$

\begin{abstract}
Today, websites that sell ready-made clothing products; depending on the technological change and development offer various alternatives to their customers and market their products. Examining the concepts of benefit, risk, trust, and value can reveal important results in the online shopping behavior of consumers towards websites. In this respect, within the scope of research trust theory, the main purpose of the research is the levels of online benefits and risks perceived by consumers from websites, trust in the site, and the value of the site in the eyes of consumers. For this purpose, three models were created in the research. In the first model, the moderator effect of risk on the effect of benefit on trust was investigated. In the second model, the effect of the site on the value of the site in the eyes of the consumer was examined in terms of benefit and risk. The third model explores the mediating effects of trust in the impact of benefit and risk on the site's value. As a result of the research, it has been determined that the online benefit perceived by the consumers from the websites has an online risk moderator effect on their trust in the website. Online benefit positively and significantly affected the trust on the site, while online risk affected the trust on the site negatively and significantly. In addition, consumers' online risk perceptions negatively and significantly affected the value of the site. Trust in the site has had a full mediating effect on the impact of online risks on the site's value. In addition, consumers' online utility perceptions were found to have a positive and significant effect on the value of the site. The partial mediating effect of trust in the site was found in the effect of online benefit on the value of the site. The trust in the site in the research has positively and significantly affected the value of the site for the consumer.
\end{abstract}




\section{Giriş}

Günümüzde tüketiciler tarafından elektronik ticaret yaygın olarak kullanılmaktadır. Elektronik ticarette teknolojik değişimlere bağlı olarak tüketicilerin internete erişimi daha kolay hale gelmiştir. Ayrıca elektronik ticaret için tüketiciler mobil kullanımı fazlaca tercih etmektedirler. Bu durum hızlı bilgi paylaşımına ve bireysel yönlendirmelere sebep olabilmektedir. Fiziksel bağlantı kurulmadan elektronik olarak tarafların iletişim kurdukları her türlü ticari iş elektronik ticarettir (Yıldız, 2018: 171). Tüketiciler elektronik ticaret ile satın aldıkları ürünleri web siteleri yardımı ile gerçekleştirmektedirler. Ayrıca tüketiciler ürün/hizmetlere web siteleri aracılığıyla farklı sitelerden kolaylıkla erişim sağlayıp temin edebilmektedirler.

Türkiye'de hazır giyim sektöründe yıllara göre sanal ticarette önemli artışlar olduğu gözlemlenmektedir. Tüketiciler açısından elektronik ticaret web siteleri aracılı̆̆ i ile gerçekleştirilmektedir (Akyüz, 2014: 94). Bilişim Sanayicileri Derneği (TÜBİSAD) 2021 yılı raporunda açıkladığı veriler incelendiğinde, yıllara göre akıllı telefon kullanıcı sayılarında önemli bir artış olduğu gözlemlenmektedir ( 2015 yılı 1,9 milyar adet iken 2023 yılı tahmini 4,3 milyar). Aynı raporda teknolojik gelişmelere bağlı olarak önümüzdeki yıllarda nesnelerin interneti kullanımının (birçok sektör için müşteri deneyimi oluşturduğu vurgulanmakta ve 2020 yılı 8,7 milyar adet iken 2030 yılı tahmini 25,4 milyara ulaşacağ zekânın (\%66) oldukça etkili olabileceği vurgulanmaktadır. Bunun yanında raporda Covid-19'un birçok sektörü olumsuz etkilerken elektronik ticareti pozitif olarak (2020 yılı \%25'in üzerinde büyüme ile) etkilediği belirtilmektedir (TÜBİSAD, 2021a: 34-97). TÜBİSAD'ın 2021 yılı raporunda dünyada 2020 yılında interneti kullanan her 5 kişiden 4'ünün elektronik ticareti tecrübe ettiği vurgulanmaktadır. Araştırmada Türkiye' de elektronik ticaretin Gayri Safi Yurtiçi Hasıla (GSYH) içerisindeki payının \%4,5'e eriştiği ifade edilmektedir (TÜBİSAD, 2021b: 7-8). Bu durum günümüzde elektronik ticarette teknolojiye bağlı olarak yapay zekâ ürünlerinin (telefon, bilgisayar, tablet ve yapay zekâ programları gibi) hem tüketiciler hem de satıcı firmalar tarafından kullanımının daha da arttırabileceğini göstermektedir. Özellikle elektronik ticarete bağlı olarak tüketicilerin web sitelerinde gerçekleştirdikleri alışverişlerde; güven, risk, fayda ve değer kavramlarının incelenmesinin literatüre önemli katkıları olabileceğini ortaya koymaktadır. Tüketiciler, web ortamı ve sosyal paylaşım sitelerinde zaman geçirmesi (arkadaş çevresi ile bilgi paylaşımı, sanal ortamlarda takip edilenler, aynı anda hem satıcı hem müşteri olunabilecek web sitelerinden alışverişler gibi) ürün satın almalarını etkilemektedir. $\mathrm{Bu}$ ve benzer etmenler tüketicilerin web sitelerinde algıladıkları çevrimiçi fayda düzeylerini, çevrimiçi risklerini, sitelere olan güvenlerini ve sitelerin tüketiciler gözündeki değerini etkileyebilmektedir. Bu açıdan araştırmada teknolojinin gelişmesine ve çevresel etmenlere bağlı olarak elektronik ticarette meydana gelen değişimler, tüketicilerin web sitelerine yönelik güvenlerini, algıladıkları faydaları, riskleri ve sitenin tüketici gözündeki değerinin birbirleri ile ilişkilerini ortaya koyan bir çerçeve çizilmiştir.

Belirli bir sistem için güven teorisi, aracıların güvendiği sistemin güvenlik mekanizmalarının davranışını (ya da işlevlerini) belirleyen bir dizi kuraldan oluşur (Ma ve Orgun, 2006: 451). Bu kurallar tüketiciler açısından, web sitelerinden yapılan alışverişlerde güvenilir bir mekanizmanın gerekliliğini göstermektedir. Literatürde güven teorisi bağlılık ile birlikte araştırılmış ve güven teorisi açısından pazarlama biliminde hem işlevsel hem de işlevsiz ilişkilerin anlamlandırılması gerektiği vurgulanmıştır (Morgan ve Hunt, 1994: 33). Castelfranchi ve Falcone (2005: 86) sosyobilişsel durumu güven kuramı kapsamında değerlendirdikleri araştırmalarında güvenme eyleminin epistemik olarak rasyonel bir tutuma ve algılanan riske göre yeterli bir dereceye sahip olması durumunda güvenin rasyonel olduğunu vurgulamışlardır. Onlar ayrıca beklentinin sağlam temele dayanması ve güven derecesinin algılanan riski aşması durumunda güvenme kararının öznel olarak rasyonel olabileceğini ifade etmişlerdir. Mukherjee ve Nath (2007: 1196) güven teorisi kapsamında gerçekleştirdikleri araştırmalarında web sitelerine yönelik güven oluşturmanın ve teknolojik özelliklere duyulan güvenin, tüketici güveni sağlamada önemli bir etkisi olduğunu ortaya koymuşlardır. Wang ve diğerleri (2016: 636) bağl1lık ve güven teorisi kapsamında tüketicilerin web sitelerinden ürün satın almalarına yönelik araştırmalarında, elektronik ticarette sistem tasarlamanın önemli olduğunu, tüketicilerin satın alma süreçlerinde karmaşıklığı azaltabileceği, rahatlığı ve 
güveni artırarak endişelerden kaynaklanabilecek belirsizlik ve riskleri azaltabileceği ve bu durumun tüketicilerin algıladıkları değeri ve memnuniyeti artırabileceğini ifade etmişlerdir. Isaeva ve diğerleri (2020: 1050) ise güven kuramına ilişkin araştırmalarında tüketici güveninin; satış etkinliği, sadakat, bağlılık, işbirliği ve başarılı ilişkiler açısından satıcı firmalar için rekabet avantajı sağladığını vurgulamışlardır. Araştırmada literatürden farklı olarak güven teorisi, tüketicilerin ürün satın aldıkları sitelere yönelik güven, fayda, risk ve değer açısından bütünsel olarak değerlendirilmeye çalışılmıştır.

Tüketicilerin kişisel bilgilerini toplayan web siteleri, demografik bilgileri temel alarak pazarı bölümlere ayıramazlar (Hann vd., 2002: 8). Çünkü web siteleri yalnızca tasarım açısından tüketicilerin beklentilerini karşılamakla kalmayıp aynı zamanda hedeflenen müşterileri çekmek için bir pazarlama stratejisi uygulamaları gerekir. $\mathrm{Bu}$ açıdan web siteleri tanıtımlarını gerçekleştirebilmek için sosyal medyayı kullanarak pazarlama eğilimlerini arttırmak zorundadırlar (Ghandour, 2015: 215). Bu durum web sitelerinden yapilan alışverişlerde tüketicilerin etkilenebileceği birçok mekanizmanın var olabileceğini göstermektedir. Ayrıca web siteleri müşterilerine sağladıkları imkânlar ile fayda, risk, güven ve değer gibi tüketici algılarını etkileyebilirler.

Günümüz Covid-19 salgınının etkileri dikkate alındığında, yüz yüze ticaret dışında web sitelerinden gerçekleştirilen elektronik ticaretin önemi günden güne artmaktadır. Özellikle tüketiciler web sitelerindeki alternatifleri inceleyerek satın alacakları hazır giyim ürünleri arasında kolaylıkla tercih yapabilmektedirler. Tüketiciler gerçekleştirdikleri alışverişlerde sitelere yönelik çeşitli değer algıları ve güven duyguları geliştirebilmektedirler. Bu durum sitelerden gerçekleştirilen ürün alışverişinde çevrimiçi fayda ve risklerin önemli etkileri olabileceğini göstermektedir. Tüketicilerin web sitelerine yönelik çevrimiçi fayda ve risk algıları, sitenin genel görünümünden (kullanım kolaylığı, bilgi içerikleri, renk ve reklam içerikleri gibi), satın aldıkları hazır giyim ürünlerinden, ürünün pazarlanmasından, ürüne ilişkin indirim ve hediye gibi uygulamalardan etkilenebilir. Bu değişkenler genel itibari ile tüketicini web sitesine olan güvenini ve sitenin tüketici açısından değerini etkileyebilir.

Çevrimiçi alışverişin yaygınlaşması teknoloji odaklı bir bakış açısı ile tüketicilerin ilgisini çekmektedir. Bu durum tüketicileri elde tutmayı amaçlayan satıcıları birçok tüketici odaklı araştırmaya yönlendirmektedir (Delafrooz vd., 2009: 201). Bu çerçevede gelecek araştırmaların ideal olması için geniş bir web sitesi örneğinin dikkate alınması gerekmektedir. Çünkü belirli bir marka ile sınırlı kalmayan web siteleri hem hizmet hem de ürün satışında bulunup çeşitli görevler üstlenerek daha geniş bir içeriğe sahip olabilmektedirler (Cyr, 2008: 68). Bu geniş içeriklerde önemli bir yere sahip olan reklam aracı; bilgilendirici, eğlenceli ve tüketicilerin karar vermesi için yararlı olabilecektir (Schlosser vd., 1999: 42). Bu açıdan araştırmada tüketicilerin ürün ve hizmet üreten ve geniş kitlelere hitap edebilen çeşitli hazır giyim sitelerini (alibaba.com, boyner.com, collezione.com, defacto.com, gittgidiyor.com, hepsiburada.com, koton.com, trendyol.com, mavijeans.com) tercih etmelerinde hangi reklam aracından (çevremdeki kişiler, dergi reklamları, gazete reklamları, internet reklamları ve televizyon reklamları) etkilendikleri, bu sitelerden alışveriş yaparken tüketicilerin çevrimiçi fayda algıları, çevrimiçi risk algıları, siteye güven duyguları ve sitenin onların gözündeki değerinin ne derece etkili olduğunun belirlenmesi amaçlanmıştır.

\section{Kavramsal Çerçeve}

\section{1. Çevrimiçi Faydalar}

Çevrimiçi olarak kullanılan web sitelerinde, tüketicilerin çevrimiçi güvenleri ile diğer alışveriş ortamlarındaki güvenleri arasında büyük bir fark oluşabilmektedir. Tüketicilerin web sitelerinde çevrimiçi olmaları ile başkalarının potansiyel zararlarını, iyi niyetlerini ve kendileri için neyin makul olup ya da olamayacağını değerlendirebilme zorlukları yaşayabilmelerinden bu farklar kaynaklanabilmektedir. Bu yüzden tüketiciler sanal olarak çevrimiçi etkileşime girebilirler. Ancak etkileşimlerin güvenilir olup olmadığı konusunda tüketiciler farklı kararlar alabilmektedirler (Friedman vd., 2000: 40). Bu kararlarda tüketiciler alışveriş yaptıkları sitelere yönelik çeşitli faydalar algılayabilirler. Özellikle sitelerde satışı yapılan ürünler için oluşturulan fırsatlar veya kampanyalar 
(indirim, hediye, kupon, ücretsiz kargo imkânı vb.) tüketicilerin algıladıkları fayda düzeyine etki edebilmektedir.

Tüketicilerin çevrimiçi olmalarında güven, bireylerin etkileşimini kolaylaştırır ve mevcut web sitelerine bağlı kalmalarını teşvik eder (Hajli, 2013: 393). Bazı çevrimiçi güven unsurları bütün paydaşlar ile uyumlu olabilir veya olmayabilir. Örneğin açık ve tarafsız bir bilgi tüm paydaşlar için ortak bir ihtiyaçtır. Firmaların iş ahlakı görüntüleri de paydaşları farklı şekillerde etkiler. Farklı sitelerden alışveriş yapılsa da fiyatların şeffaf olması müşteriler arasında güveni artırabilecekken firma satıcıları açısından olumsuz olarak değerlendirilir (Shankar vd., 2002: 329-330). Böylece tüketicilerin internetin güvenilirliğine dair görüşlerini ve çevrimiçi satın alma isteklerini etkileyebilmektedir (George, 2004: 201). Web sitelerinde uygulanan satış politikaları genel olarak hem tüketicileri hem de satıcı firmaları faydası açısından etkileyebilir. Tüketiciler açısından web sitelerinin uygulayacağı şeffaf politikalar, memnuniyetini artıracağı için çevrimiçi algılanan faydalara da önemli katkıları olabilir.

Tüketicilerin çevrimiçi alışverişleri üzerine daha önce yapılan çalışmalar (web sitelerine yönelik çevrimiçi faydaları, çevrimiçi riskleri, siteye güven ve sitenin tüketici gözündeki değerini ortaya koyabilen) genel olarak şu şekildedir. Sheehan ve Hoy (2000: 62-71) Federal Ticaret Komisyonu' nun işletmelerin çevrimiçi ticareti artırmaları için tüketicilerin davranışları ile ilgili olarak dikkat edilmesi gereken beş temel ilkenin olduğunu vurgulamışlardır. Bu ilkeleri "uyarı, seçim, erişim, güvenlik ve düzeltme" olarak sıralamışlardır. Burada işletmelerin bilgi uygulamaları ile tüketicilere seçim yapma yetisi vererek bilgilere erişim kolaylığı sağladığını belirtmişlerdir. Onlar ayrıca toplanan bilgiler ile tüketicilerin güvenliği sağlanarak yanlışların düzeltilmesinin amaçlandığını vurgulamışlardır. Çevrimiçi ticarette tüketici gizliliğini, endişelerini anlayan ve bu endişeleri pazarlama iletişiminde uygulayan pazarlamacıların başarılı olduklarını ifade etmişlerdir. Shankar ve diğerleri (2002: 341) ise araştırmalarında çevrimiçi olmanın faydalarında güvenin önemli olduğunu vurgulayarak duygusal rahatlık, kalite ve yardımseverlik içeren çok boyutlu bir yapı olduğunu vurgulamışlardır. Ayrıca web sitesinin özelliklerinin, müşteri özelliklerinin ve diğer faktörlerin çevrimiçi güvenin belirleyicileri olduğunu vurgulamışlardır. Zhou ve diğerleri (2007: 5456) tüketici değişkenleri ve tüketicilerin çevrimiçi alışveriş davranışları çeşitli açılardan incelemişlerdir. Tüketicilerin çevrimiçi alışveriş davranışlarının perakende satış uygulamalarını büyük ölçüde iyileştirdiği sonucuna ulaşmışlardır. Bunun yanında olumlu duyguların çevrimiçi alışverişi olumlu yönde etkileyeceğini vurgulamışlardır. Hsu (2008: 171) tüketicilerin çevrimiçi olmalarında güven faktörünü dikkate alarak; itibar, marka, sistem güvencesi, web sitesinin kalitesi, üçüncü tarafın güvencesi ve müşteri hizmetleri gibi çevrimiçi güven faktörlerine odaklanılması gerektiğini ortaya koymuştur. Öztüren (2013: 2006-2007) ise araştırmasında çevrimiçi sosyal inceleme ağının yetkinliği, öngörülebilirliği, bütünlüğü ve yardımseverlik algılarının yüksek seviyede olmasının, tüketiciler tarafından çevrimiçi sosyal inceleme ağında daha fazla güven oluşturduğu sonucuna ulaşmıştır. Aynı zamanda bütünlük, öngörülebilirlik, iyi niyet ve yeterlilik arasında istatistiksel olarak anlamlı ilişkiler olduğunu ortaya koymuştur.

\section{2. Çevrimiçi Riskler}

Güven, bir tüketicinin satın alma bilgilerinin uygunsuz kullanılması da dahil elektronik ticarette karşılaştığı sosyal karmaşıklığın azaltılmasına yardımcı olmak için tüketicilerin olası davranışlarının dışa vurulmasıdır. Bu durum tüketicilerin siteye güvenlerinin onları çevrimiçi faaliyetlere teşvik edebileceğini ortaya koymaktadır (Gefen vd., 2003: 60). Yani güven çevrimiçi işlemleri kolaylaştırmak için kritik öneme sahiptir. Güven tüketicinin satın alma niyetinin güçlü ve pozitif bir göstergesidir (Lowry vd., 2008: 215). Bu açıdan güvensizliğinin ve güvenin birlikte var olabileceği düşüncesi ile eğer tüketici gözünde güvensizlik fazla ise bu durumlar elektronik ticarette yüksek düzeyde korkuya ve tüketicilerin temkinli davranmalarına sebep olabilmektedir (McKnight vd., 2004: 39-40). Tüketicilerin satın aldığı ürünler de çevrimiçi davranışlarında sitenin güvenilir olması veya olmaması ürün satın alma kararını şekillendirmektedir. Çevrimiçi ortamda güvensizliğin fazla olması, tüketici için risk katsayısının yüksek olduğu algısını oluşturabilecektir. Aksi bir durumda ise, risk algısı daha düşük olabilir. Ayrıca tüketicilerde alışveriş yaptıkları site ya da sitelere karşı algıladıkları risk algısı onların güvenlerini ve siteye yönelik değer algılarını etkileyebilmektedir. 
Literatürde tüketicilerin çevrimiçi olmalarına yönelik risk algılarını ve güven duygularını ortaya koyabilen çalışmalar genel olarak incelendiğinde; McKnight ve diğerleri (2002b: 352) internetten satış yapan tüketiciler genellikle güvenmek ya da güvenmemek yerine satış yerinin belirli nitelikleri ile ilgili belirli inançlara sahip olduklarını vurgulamışlardır. Tüketicilerin çevrimiçi davranışlarında güven ve güvensizlik durumlarının yanı sıra inanç kavramının da önemli bir değişken olduğu görülmüştür. Ahuja ve diğerleri (2003: 150) tüketicilerin güven ve gizlilik endişelerinin çevrimiçi alışverişin önündeki en büyük engel olduğunu ortaya koymuşlardır. Hatta popüler olan düşüncenin aksine bu faktörün fiyattan daha önemli olduğu sonucuna ulaşmışlardır. Tsai ve diğerleri (2011: 266) tüketicilerin kişisel verileri değerlendirmesinde gizlilik bilgilerinin çevrimiçi alışveriş kararlarında etkili olduğunu saptamışlardır. Tüketicilerin genellikle orta veya üst düzeyde gizlilik sunan sitelerden alışveriş yaptıklarını ifade etmişlerdir. Ayrıca, tüketicilerin mahremiyetleri için prim ödemeye istekli olabilecekleri sonuçlarına ulaşmışlardır. Oyeyemi ve diğerleri (2018: 15) Nijerya' daki tüketicilerin çevrimiçi davranışları fazla tercih etmediklerini, çevrimiçi alışverişi riskli algıladıkları ve çevrimiçi alışverişin onlar için bir yenilik olduğundan insanların bu konuda fazla deneyimlerinin olmadığını tespit etmişlerdir. Yıldız ve Kırmızıbiber (2020: 504) ise tüketicilerin online ürün satın alma davranışlarında kişilik özellikleri ile güven ve risk alma davranışları arasında pozitif ilişkiler olduğunu belirlemişlerdir.

\subsection{Siteye Güven}

Elektronik ticarette güven önemli bir unsurdur (Yıldız ve Çilingir, 2010: 415). Güven satın alma niyetinin önemli bir belirleyicisidir (Everard ve Galletta, 2005: 78). Güven sadece kısa vadeli bir problem değil aynı zamanda elektronik ticarette tüketicilere yönelik potansiyeli gerçekleştirmede önemli uzun vadeli bir değerdir (Grabner-Kraeuter, 2002: 43). Bu açıdan web sitesinin güvenirliği, kullanıcıların web sitesi ile ilgili uzmanlıklarını ve güvenilirlik algılarını tanımlar. Web sitesinin görsel çekiciliği tüketicinin estetik tasarım kalitesine ilişkin değerlendirmeleri belirlemektedir. Web sitesine güven ise, müşterilerin web sitesinin tavsiyelerine göre kendinden emin olduğunu ya da kendinden emin olmadığı duygusunu hissettirmek ile açıklanabilir (Cugelman vd., 2009: 459). Ayrıca web sitelerinde satışı yapılan ürünlerin orijinal, hatasız ve zamanında tüketiciye sunulmasının güven açısından önemli bir etkisinin olabileceğini gösterir.

Müşteri güveni oluşturmak sürekli güven gelişiminin yanı sıra teknoloji ve iş uygulamalarını içeren karmaşık bir süreçtir (Siau ve Shen, 2003: 94). Tüketicilerin siteye güven geliştirmeleri, siteyi tecrübe etme kararı verdikten sonra başlar. Bu aşamada tüketicilerin güven niyeti ile eski deneyimlerini de kullanarak web sitesini daha fazla keşfetme yoluna giderler. Tüketiciler deneyimlerini devam ettirmeye karar verir ise taahhüt aşamasına geçerler. Bu aşamada tüketiciler web sitesi üzerinden satıcı ile etkileşime girerler ve "bu satıcı ile iş yapmalı mıyım?" sorusuna cevap ararlar. Tüketiciler ürün satınalma kararını verdiklerinde (niyete güvenme) artık kişisel bilgileri ile alışverişte bulunurlar ve siteye olan güveni ile ürün satınalma davranışı sergilemiş olurlar (McKnighht vd., 2000: 533). Bu durum tüketicilerin ürün satın alma sonrası site ile iletişimlerinin de önemli olabileceğini göstermektedir.

Literatürde tüketicilerin satın aldıkları ürünlerde sitelere olan güvenlerini ortaya koyabilecek çalışmalar genel itibari ile incelendiğinde; Urban ve diğerleri (2000: 40-41) web sitesine olan güveni geliştirmenin üç aşaması olduğunu vurgulamışlardır. Bunlardan birincisi internete ve belirli bir web sitesine güven, ikincisi gösterilen bilgilere güven ve üçüncüsü ise teslimatı yerine getirme ve hizmete duyulan güven olarak sıralamışlardır. Buna ilaveten söz konusu üç maddenin de iyi bir şekilde yürütülmesi gerektiğini vurgulamışlardır. Cyr ve diğerleri (2005: 32-36) dört ülkenin tüketicilerinin (ABD, Almanya, Japonya ve Kanada) siteye güven derecelerini yerel ve yabancı site düzeyinde incelemişlerdir. Almanların en fazla sitelere güvenen bireyler olduğunu Japonların ise en az güvene sahip olduklarını belirlemişlerdir. Martin ve Camarero (2008: 552-554) tüketicilerin siteye güvenleri ve sitelerin gizlilik politikalarını incelemişlerdir. Tüketicilerin sitelere verdikleri önemin ve güvenin belirleyici unsurlarının daha önce yaptıkları alışverişten duydukları memnuniyetin (olumlu deneyim) önemli olduğunu tespit etmişlerdir. Aynı zamanda, potansiyel kullanıcıların web sitesinin sunduğu güvenlik ve mahremiyete dayanarak daha rasyonel bir güven gösterdiklerini, motive edilmiş bireylerin ise web sitesi tarafından sunulan hizmet kalitesine değer 
verdiklerini ve bu durumun onları tatmin ettiğini dolayısı ile web sitesine de güvenlerini artırdığı sonuçlarına ulaşmışlardır. Zhu ve diğerleri (2011: 12-15) ise siteye güvenin çevrimiçi alışveriş sırasında tüketicilerin algılanan risklerini önemli ölçüde azalttığını ifade etmişlerdir. Ayrıca tüketicilerin algılarındaki kullanım kolaylığı, algılanan fayda, siteye güven ve algılanan riskler ile ürün satınalma niyetleri arasında hem doğrudan hem de dolaylı etkiler olduğu sonuçlarına ulaşmışlardır.

\subsection{Sitenin Değeri}

Gündelik hayatta tüketiciler internet üzerinden birçok sitede faaliyette bulunmaktadırlar. Öyle ki geniş ve güvenilir bir ağa sahip bireyler kişisel olarak kendilerini iyi hissetmedikleri zamanlar bu sitelerden duygusal destek alabilmektedirler. Bu destekler bu tarz sitelere (ağlara) üyelerin güvenini daha fazla arttırabilir (Valenzuela vd., 2009: 878). Bu durum ise web sitesinin verimliliği ve kullanılabilirliği ile satın alma sürecini kolaylaştırabilir ve tüketicinin siteye verdiği değeri artırabilir (Shergill ve Chen 2005: 91). Genellikle markalı ürünler ve hizmetler tüketicilerde daha olumlu izlenimler uyandırmaktadır. Örneğin çevrimiçi müşteri hizmetlerini iyileştirmenin en etkili yöntemlerinden biri garanti vermektir. Ayrıca web pazarında verimli müşteri hizmetleri, çalışanların iyi oluşu, duyarlı bir servis organizasyonu, basit bir iade süreci ve sipariş takibinin kolaylığı gibi durumlar da web sitesinin tüketici gözündeki değerini etkileyebilmektedir (Shergill ve Chen, 2005: 92). Ek olarak sitenin tüketici gözünde değerli olabilmesi için web sitesinin rakip olarak değerlendirdiği web sitelerinden farklı olduğu yönleri ortaya koyabilmelidir. Bu süreç şu dört unsur ile "hedef belirleme, web sitesi, pazarlama ve internet güvenliği" ortaya koyulabilir. Örneğin internet güvenliği; satın alma davranışı, web sitesinden memnuniyet ve web sitesine duyulan güven ile ilişkilidir. İşletmeler çevrimiçi faaliyetlerini güvenli bir şekilde yürütülmesini sağlamak için gereken tüm adımları göz önünde bulundurmalıdırlar (Ghandour, 2015: 207-210). Bu durum web sitelerinin de teknolojik değişime ve gelişime bağlı olarak sürekli kendilerini yenilemeleri gerekebileceğini de göstermektedir.

Herhangi bir hizmet şirketi bir web sitesini kullanarak müşterilerinde sadakat duygusu oluşturabilir. Ancak bu sadakatin korunması zor olabilir. Bu açıdan tüketicilere yönelik ilişkisel bağlantı stratejileri web kullanıcıları ile kullanıcı olmayanlar arasında farklı etkiler oluşturabilir (Lin vd., 2003: 119). Park ve Kim (2008: 161) çevrimiçi alışverişlerinde firmaya olan sadakatin bilgi memnuniyeti ve ilişkisel fayda ile ilişkili olduğunu belirlemişlerdir. Ayrıca tüketiciler bilgi memnuniyeti, ilişkisel fayda, ürün-hizmet kalitesi ve güven algılarından önemli ölçüde etkilendiklerini vurgulamışlardır. Bu açıdan bakıldığında tüketicilerin gözünde sitenin değerli olup olmamasında ürün satışı yapan firmaların müşteri sürekliliği için uyguladıkları politikalarstratejiler büyük önem arz ettiği anlaşılmaktadır.

Literatürde siteye güven ve sitenin tüketici gözündeki değer açısından incelendiğinde; McKnight ve diğerleri (2002a: 314) güven teorisinin, web üzerindeki çevresel ve yapısal algıları yansıtarak satıcıların algılarında farklılık oluşturabileceğini ifade etmişlerdir. Bu durumun web satıcısı ile ilgili güveni, inançları ve tutumları etkileyebileceğini vurgulamışlardır. Yapısal olarak güvenin satıcı veya site ile ilgili olmadığını genel web ortamı ile ilgili olduğu sonucuna ulaşmışlardır. Ayrıca tüketicilerin bir web sitene karşı düşük yapısal güven algılamalarının, bilinmeyen bir web tabanlı satıcıya güvenmelerinin önünde büyük bir engel teşkil ettiğini ifade etmişlerdir. Tüketicilerin güvenlerinin üst düzeyde olabilmesinin yüksek algıları ile oluşabileceği sonucuna ulaşmışlardır. Bu sonuçlar tüketicilerin siteye yönelik algılarında sitenin tüketici gözündeki değerinde tutumların ve inançların da etkili olduğunu göstermektedir. Hampton-Sosa ve Koufaris (2005: 69) ise web sitesinin becerileri ile tüketiciler tarafından kullanılabilir olmasının tüketicilerin algıları üzerinde pozitif etkileri olabileceğini ortaya koymuşlardır. Ayrıca çalışmalarında ürün satan firmaya güvenin gelecekte web sitesini kullanma niyetini olumlu yönde etkileyebileceğini vurgulamışlardır. Bu doğrultuda elde edilen sonuçlar web sitesinin tüketici gözündeki değerinde algıların ve güvenin oldukça önemli olduğunu göstermektedir. 


\section{Araştırma Yöntemi}

\subsection{Araştırmanın Amacı ve Kapsamı}

Günümüzde online pazarlamanın yoğun bir şekilde işlerlik göstermesi, tüketicileri hazır giyim ürünleri satın alma noktasında bu pazarlara yönlendirebilmektedir. Araştırma amacı doğrultusunda tüketicilerin hazır giyim ürünü satın aldıkları web sitelerinde; çevrimiçi fayda, risk, güven ve değer ilişkilerini açıklayan 3 farklı model oluşturulmuştur. Birinci modelde çevrimiçi faydanın siteye güven üzerindeki etkisinde çevrimiçi riskin düzenleyici etkisi araştırılmıştır. İkinci modelde çevrimiçi fayda ve riskin sitenin tüketici gözündeki değeri üzerindeki etkisi araştırılmıştır. Üçüncü model ise çevrimiçi fayda ve riskin sitenin değeri üzerindeki etkisinde güvenin aracı etkileri incelenmiştir.

\section{2. Örnekleme Süreci ve Veri Toplama Yöntemi}

Araştırma kartopu örnekleme yöntemi ile gerçekleştirilmiştir. Literatürde kartopu örneklemede, örneklemin rastgele seçilmesinin uygulamayı zorlaştırabileceği ve kolayda örneklem ile de desteklenebileceği ifade edilmektedir. Literatürde ayrıca kartopu örneklemenin keşfedici, nitel ve tanımlayıcı araştırmalarda da, özellikle katılımcı sayısının az olduğu ve yüksek düzeyde güvene ihtiyaç olduğu çalışmalarda yararlı metodolojik bir yöntem olabileceği vurgulanmaktadır (Baltar ve Brunet, 2012: 60). Kartopu örneklemede örnekleme ulaşmak için başka bireylerin kullanılması araştırmalarda önemli bilgi kaynağı sağlar. Bireylerin konuya ilişkin geçmiş veya şimdiki durumların bir sonucu olarak örneklemin yaşam alanı hakkında erişilebilirlikleri ve bilgiye sahip olmaları da önemlidir (Biernacki ve Waldorf, 1981: 152). Araştırmada örnekleme kolaylıkla erişim sağlayabilmek ve bireylerin yaşam alanı hakkında bilgi sahibi olabilmek için aracılar kullanılmıştır. Bu açıdan kartopu örnekleme yönteminin avantajlarından faydalanılmıştır.

Literatürde kartopu örnekleminin dezavantajlarında ise katılımcıların araştırmaya dahil edilme olasılıklarının eşit olmadığı vurgulanmaktadır. Ayrıca geniş sosyal ağlara sahip olanların daha dar bir yaşama sahip olanlara oranla seçilme olasılıklarının daha yüksek olduğu vurgulanmaktadır. Sonuç olarak kartopu örnekleme yönteminde örneklem sayısının az olmasının da yeterli olabileceği vurgulanmaktadır (Jong ve Ommeren, 2002: 427). Araştırmada dezavantajlar dikkate alınarak kartopu örnekleme yöntemi ile internetten hazır giyim ürünü satın alma olasılığı yüksek olan bireyler uygulamaya alınmıştır. Araştırma uygulaması gerçekleştirilirken örneklem sayısı geniş tutularak ortalama 1500 tüketiciye erişim sağlanması hedeflenmiştir. Bu amaç doğrultusunda kartopu örnekleme yöntemi dikkate alınarak ilk etapta 45 kişiye erişim sağlanmış ve elektronik anket gönderilmiştir. Daha sonra bu tüketiciler aracılığı ile ortalama 500 tüketiciye daha erişim sağlanmıştır. Erişim sağlanılan bu tüketicilerden toplamda 342 kişi ankete katılım sağlamıştır. Çalışmanın verileri 2019 yılı içerisinde Türkiye' de İzmir ilinin Buca ilçesinde yaşayan 342 tüketiciye elektronik anket yöntemi uygulanarak gerçekleştirilmiştir. Araştırmada 34 tüketici internet aracılığ1 ile web sitelerinden ürün satın almadıklarını ifade etmişlerdir. Bu sebeple araştırmanın hipotez modelleri 308 tüketicinin verdiği cevaplar dikkate alınarak test edilmiştir. Krejcie ve Morgan (1970: 608) araştırmalarında ortalama 1500 kişilik bir evren için 306 kişinin örnekleme dahil olmasının yeterli olduğunu ifade etmişlerdir. Bu durum 308 tüketicinin verdiği cevaplar ile yapılan analizin yeterli örnekleme sahip olduğunu ortaya koymaktadır. Uygulanan çalışmada web siteleri incelendiği için çalışma verilerinin elektronik olarak elde edilmesinin daha rasyonel sonuçlar verebileceği düşünülmüştür. Araştırma analizlerinde AMOS ve SPSS programlarından faydalanılmıştır.

\subsection{Veri Toplama Araçları}

Araştırmanın anketinde toplamda tüketicilere 28 adet soru yöneltilmiştir. Tüketicilerin demografik bilgilerine yönelik sekiz adet (cinsiyet, yaş, mezuniyet, meslek, gelir, web sitelerinden ürün satın alma durumları, web site, reklam aracı) soru yer almaktadır. Ankette bulunan dört ölçek (CF, CR, SG ve SD) belirlenirken literatürde konuya ilişkin gerçekleştirilen araştırmalar dikkate 
alınmış olup bu ölçekler 20 ifadeden oluşmaktadır. Ölçeklere ilişkin ifade sayısı ve kaynakları Tablo 1'de belirtilmiştir.

Tablo 1. Araştırmanın Ölçekleri

\begin{tabular}{|l|c|l|}
\hline \multicolumn{1}{|c|}{ Ölçek } & \multicolumn{1}{c|}{ Maddeler } & \multicolumn{1}{c|}{ Kaynak } \\
\hline Çevrimiçi Faydaları (CF) & 4 Ifade & Loureiro 2013 \\
\hline Çevrimiçi Riskleri (CR) & 5 Ifade & McKnight vd., 2002a; Loureiro 2013 \\
\hline Siteye Güven (SG) & 5 Ifade & $\begin{array}{l}\text { Gefen vd. 2003; Shergill ve Chen 2005; Martin } \\
\text { ve Camarero 2008; Cyr vd., 2008 }\end{array}$ \\
\hline Sitenin Değeri (SD) & 6 Ifade & Chang vd. 2015; Wang vd. 2007 \\
\hline
\end{tabular}

Araştırmanın ölçekleri oluşturulurken Loureiro (2013) tüketicilerin çevrimiçi olmalarının faydası ölçeğinden dört soru alınmıştır. McKnight ve diğerlerinin (2002a) tüketicilerin çevrimiçi riskleri ölçeğinden dört soru ve Loureiro' nun (2013) çevrimiçi riskleri ölçeğinden bir soru çalışmaya eklenmiştir. Tüketicilerin siteye güven ölçeğine Gefen ve diğerlerinin çalışmasından bir soru, Shergill ve Chen' in (2005) çalışmasından iki soru, Martin ve Camarero'nun (2008) çalışmalarından bir soru ve Cyr ve diğerlerinin (2008) araştırmasından bir soru eklenmiştir. Çalışmada sitenin tüketici gözündeki değeri ölçeğine, Chang ve diğerlerinin (2015) çalışmalarında müşteri bazlı marka değeri ölçeğinden alınan beş soruda uyarlama yapılarak araştırmaya dahil edilmiştir. Bu ölçeğe ek Wang ve diğerlerinin (2007) çalışmalarında web sitesinin müşterisi olma niyeti ile ilgili ölçekten alınan bir soru çalışmada tüketici açısından sitenin değeri ölçeğine uyarlanarak eklenmiştir.

\subsection{Araştırmanın Modeli ve Hipotezleri}

Araştırmada tüketicilerin web sitelerinden yaptıkları hazır giyim ürün siparişleri dikkate alınarak çevrimiçi fayda, çevrimiçi risk, siteye güven ve sitenin değeri ilişkileri güven teorisi kapsamında değerlendirilmiştir. Literatürdeki araştırmaların çoğu tek bir alana odaklanırken bu araştırma birden fazla alanda veriler değerlendirilmektedir. Araştırma ile farklı sitelere üye olup alışveriş yapan tüketicilerin güven ve endişeleri araştırılırken davranış farklılıkları açıklanmaya çalışılmıştır. Yani birden fazla hazır giyim ürünü satışı yapan web sitesinin kültürel veya teknik işlevselliklerinin tüketicilerin tercihlerini (davranışlarını) nasıl etkileyebildiği araştırılmıştır (Dwyer vd., 2007: 342). Araştırma modelleri oluşturulurken Loureiro (2013), Chang ve diğerleri (2015), Cyr ve diğerleri (2008), Martin ve Camarero (2008), Wang ve diğerleri (2007), Shergill ve Chen (2005), Gefen ve diğerleri (2003) ile McKnight ve diğerlerinin (2002a) çalışmalarından faydalanılmış olup, Şekil 1'deki gibi tasarlanmıştır.

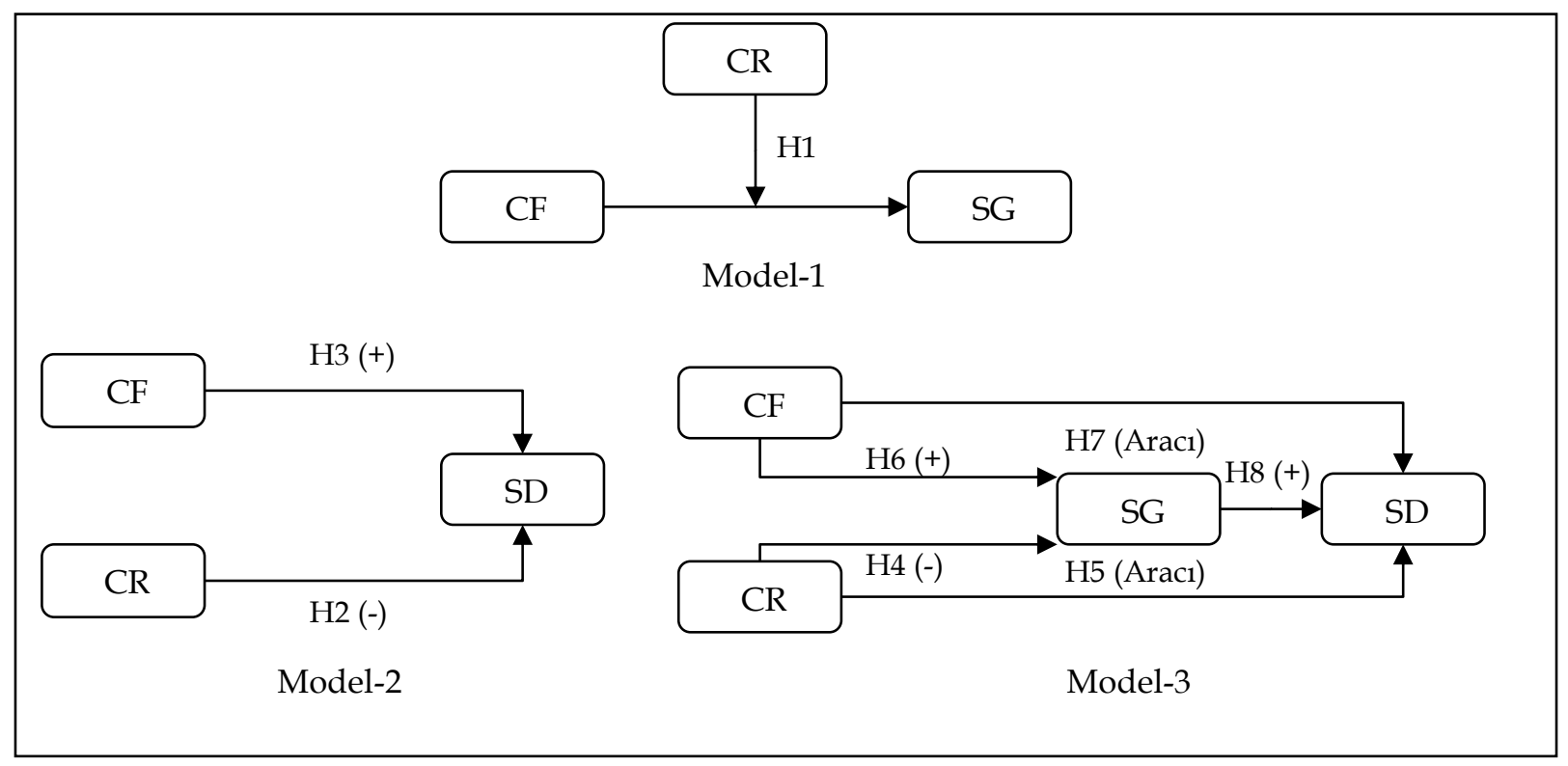

*CF=Çevrimiçi Fayda, $\mathrm{CR}=$ Çevrimiçi Risk, $\mathrm{SD}=$ Sitenin Değeri, $\mathrm{SG}=$ Siteye Güven

Şekil 1. Araştırmanın Modelleri 
Şekil 1'de belirtilen araştırma modellerine ilişkin oluşturulan hipotezler aşağıdaki gibi ifade edilebilir.

H1: Tüketicilerin web sitelerinden alışverişlerinde algıladıkları çevrimiçi faydaların siteye olan güvenleri üzerindeki etkisinde algıladıkları çevrimiçi riskler düzenleyici etkiye sahiptir.

$\mathrm{H} 2$ : Tüketicilerin web sitelerinden alışverişlerinde algıladıkları çevrimiçi riskler sitenin tüketici gözündeki değerini negatif ve anlamlı olarak etkiler.

H3: Tüketicilerin web sitelerinden alışverişlerinde algıladıkları çevrimiçi faydalar sitenin tüketici gözündeki değerini pozitif ve anlamlı olarak etkiler.

H4: Tüketicilerin web sitelerinden alışverişlerinde algıladıkları çevrimiçi riskler siteye olan güveni negatif ve anlamlı olarak etkiler.

H5: Tüketicilerin web sitelerinden alışverişlerinde algıladıkları çevrimiçi riskler ile sitenin tüketici gözündeki değeri ilişkisinde siteye olan güvenleri aracı değişken olarak rol oynar.

H6: Tüketicilerin web sitelerinden alışverişlerinde algıladıkları çevrimiçi faydalar siteye olan güveni pozitif ve anlamlı olarak etkiler.

H7: Tüketicilerin web sitelerinden alışverişlerinde algıladıkları çevrimiçi faydalar ile sitenin tüketici gözündeki değeri ilişkisinde siteye olan güvenleri aracı değişken olarak rol oynar.

H8: Tüketicilerin web sitelerinden alışverişlerinde siteye olan güvenleri sitenin tüketici gözündeki değerini pozitif ve anlamlı olarak etkiler.

\subsection{Analiz ve Bulgular}

Bu kısımda öncelikle araştırmaya katılan tüketicilerin demografik bilgilerine yer verilmiştir. Daha sonra araştırma modellerinde yer alan ölçeklere doğrulayıcı faktör analizi uygulanmış ve elde edilen sonuçlar ifade edilmiştir. Araştırmanın devamında çalışma modellerine ilişkin gerçekleştirilen analiz sonuçları ifade edilmiş ve ilgili yorumlamalar yapılmıştır.

\subsubsection{Demografik Bilgiler}

Araştırmaya katılanların; cinsiyet, web sitelerinde ürün satın alıp almama durumları, eğitim durumları, yaşları, meslekleri, hangi web sitesinden hazır giyim ürünü satın aldıkları ve satın aldıkları bu ürünlerde hangi reklam aracından etkilendiklerine yönelik bilgiler Tablo 2 ' de yer almaktadır.

Tablo 2. Demografik Bilgiler

\begin{tabular}{|c|c|c|c|c|c|}
\hline Eğitim Durumu & $\mathrm{f}$ & $\%$ & Cinsiyet & $\mathrm{f}$ & $\%$ \\
\hline İlkokul & 8 & 2,6 & Kadın & 181 & 58,8 \\
\hline Ortaokul ve Lise & 124 & 40,3 & Erkek & 127 & 41,2 \\
\hline Önlisans & 64 & 20,8 & Toplam & 308 & 100,0 \\
\hline Lisans & 73 & 23,7 & Yaş & $f$ & $\%$ \\
\hline Lisansüstü & 39 & 12,7 & 18 ve altı & 10 & 3,2 \\
\hline \multirow[t]{2}{*}{ Toplam } & 308 & 100,0 & $19-29$ & 169 & 54,9 \\
\hline & & & $30-40$ & 103 & 33,4 \\
\hline Web Sitesi & $\mathrm{f}$ & $\%$ & $41-51$ & 15 & 4,9 \\
\hline Alibaba & 1 & , 3 & $52-62$ & 9 & 2,9 \\
\hline Boyner & 17 & 5,5 & 63 ve üzeri & 2 & 6 \\
\hline Collezione & 9 & 2,9 & Toplam & 308 & 100,0 \\
\hline Defacto & 22 & 7,1 & Gelir & $f$ & $\%$ \\
\hline Gittigidiyor & 20 & 6,5 & 2000 TL ve alt1 & 124 & 40,3 \\
\hline Hepsiburada & 32 & 10,4 & $2001-4000 \mathrm{TL}$ & 98 & 31,8 \\
\hline Koton & 25 & 8,1 & $4001-6000 \mathrm{TL}$ & 57 & 18,5 \\
\hline Lcw & 42 & 13,6 & 6001 TL ve üzeri & 29 & 9,4 \\
\hline Mavijeans & 10 & 3,2 & Toplam & 308 & 100,0 \\
\hline Trendyol & 94 & 30,5 & Meslek & $\mathbf{f}$ & $\%$ \\
\hline Diğer & 36 & 11,7 & İşçi & 46 & 14,9 \\
\hline \multirow[t]{2}{*}{ Toplam } & 308 & 100,0 & Memur & 61 & 19,8 \\
\hline & & & Emekli & 3 & 1,0 \\
\hline
\end{tabular}




\begin{tabular}{|l|l|c|c|l|c|c|}
\hline Reklam Arac1 & f & $\%$ & Ev Hanımı & 43 & 14,0 \\
\cline { 2 - 7 } Çevremdeki Kişiler & 152 & 49,4 & Sözleşmeli Personel & 43 & 14,0 \\
\cline { 2 - 7 } & Dergi Reklamları & 10 & 3,2 & Esnaf & 10 & 3,2 \\
\cline { 2 - 7 } Gazete Reklamları & 4 & 1,3 & Öğrenci & 59 & 19,2 \\
\cline { 2 - 6 } İnternet Reklamları & 117 & 38,0 & Serbest Meslek & 35 & 11,4 \\
\hline TV Reklamları & 25 & 8,1 & Diğer & 308 & 100,0 \\
\hline
\end{tabular}

Tablo 2' de verilen demografik bilgiler incelendiğinde; çalışmaya katılanların büyük kısmı kadın tüketicilerden (181 kişi - \%58,8) oluşmaktadır. Araştırmaya katılanların büyük kısmı ortaokul ve lise (124 kişi \%40,3) mezunu oldukları, 19-29 yaş aralığına sahip (169 kişi - \%54,9) bireylerden oluştuğu gözlemlenmektedir. Tüketicilerin aylık gelirleri dikkate alındığında 2000TL ve altı $(124$ kişi - \%40,3) ve 2001-4000 TL gelire (98 kişi - \%31,8) sahip tüketicilerin çoğunlukta olduğu gözlemlenmiştir. Çalışmaya katılanlar mesleki açısından incelendiğinde sırası ile memur (61 kişi - \%19,8), öğrenci (59 kişi - \%19,2) ve işçi $(46$ kişi - \%14,9) sıralaması ile devam etmektedir. Tüketicilerin alışveriş yaptıkları web siteleri açısından incelendiğinde en fazla trendyol (94 kişi - \%30,5) sitesinin tercih edildiği bu siteyi sırası ile lcw (42 kişi - \%13,6), diğer (36 kişi - \%11,7), hepsiburada (32 kişi - \%10,4) ve koton (25 kişi - \%8,1) sitelerinin takip ettiği görülmektedir. Tüketicilerin alışveriş yaptıkları bu sitelerde en fazla hangi reklam aracından etkilendiklerine bakıldığında; çevresindeki kişiler $(152$ kişi - \%49,4) ilk sırada olup internet reklamları (117 kişi - \%38) ve TV reklamları (25 kişi - \%8,1) şeklinde sıralandığı görülmektedir.

\subsubsection{Faktör ve Güvenirlik Analizleri}

Araştırmada her bir ölçeğin araştırma modeline uyumunu tam anlamı ile sağlayabilmek için doğrulayıcı faktör analizi gerçekleştirilmiştir. Araştırmada ölçeklerdeki maddelerin faktör yükleri dikkate alınmış (ölçek maddelerindeki her bir değerin 0,55'in üzerinde olduğu gözlemlenmiştir) ve ilgili analiz gerçekleştirilmiştir. Doğrulayıcı faktör analizi sonucu Şekil 2' de ifade edilmiştir.

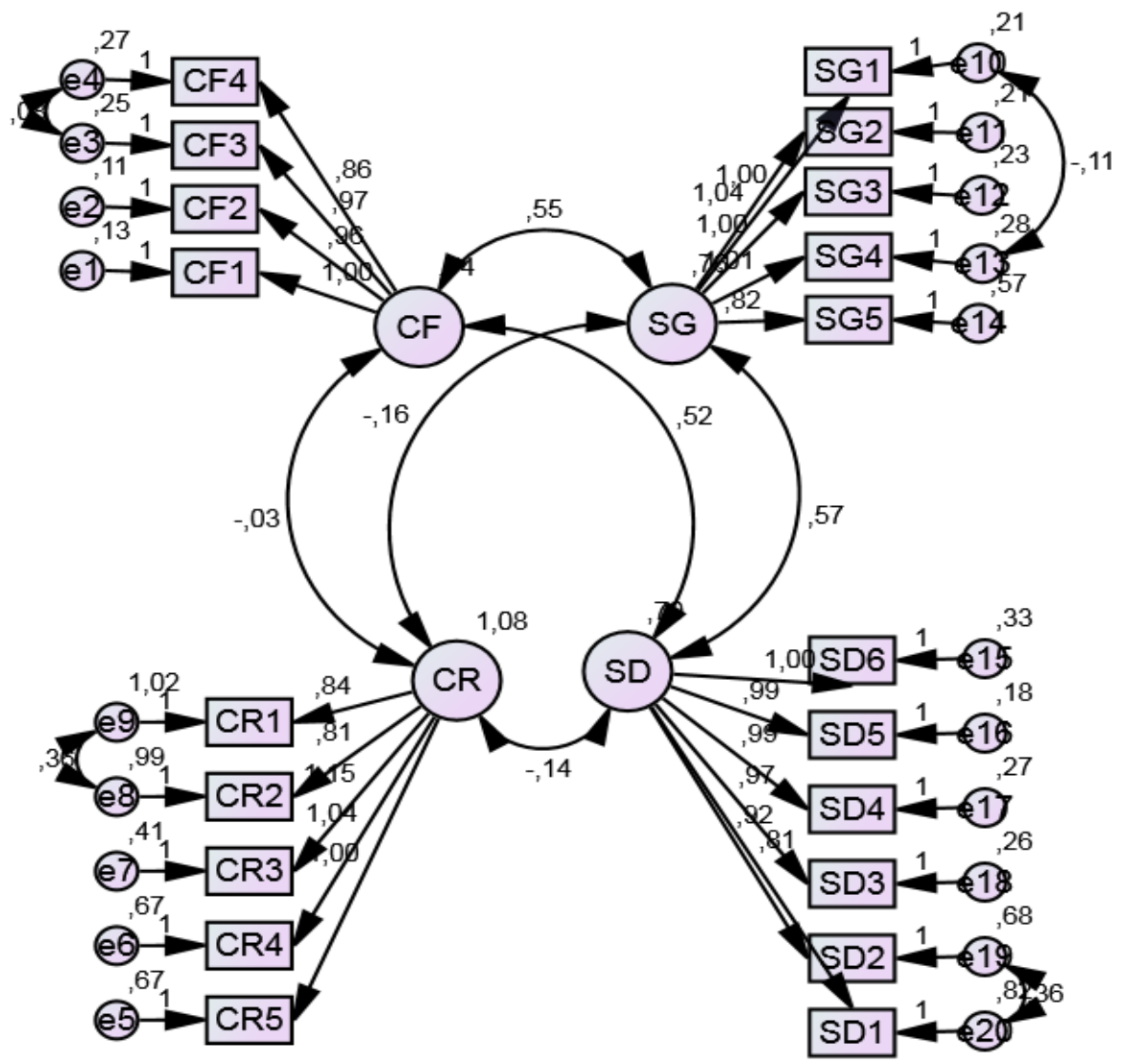

Şekil 2. Doğrulayıcı Faktör Analizi Sonucu 
Şekil 2 doğrulayıcı faktör analizinde modelin tam anlamı ile literatürde kabul edilen indekslere sahip olmasını (uyumunu) sağlayabilmek için CF3-CF4, CR1-CR2, SG1-SG4 ve SD1-SD2 maddeleri arasında modifikasyon gerçekleştirilmiştir. Analiz sonucu elde edilen verilerin literatür indeksleri ve araştırma sonucu uyum iyiliği değerleri Tablo 3'te ifade edilmiştir.

Tablo 3. Doğrulayıcı Faktör Analizi Uyum İyiliği Sonuçları

\begin{tabular}{|c|c|c|c|c|c|c|c|c|}
\hline İndeksler & CMIN/DF & RMR & IFI & GFI & CFI & TLI & RMSEA & Kaynak \\
\hline İndeks Değerleri & $<3.00$ & $<0.08$ & $>0.9$ & $>0.9$ & $>0.9$ & $>0.9$ & $<0.08$ & $\begin{array}{c}\text { Chakraborty ve Chechi, } \\
2020: 5896\end{array}$ \\
\hline Araştırma Sonucu & 2.144 & .054 & .963 & .907 & .963 & .956 & .061 & Uyumlu \\
\hline
\end{tabular}

Tablo 3 'te elde edilen sonuçlar dikkate alındığında araştırmanın uygulanabilir sonuçlar ortaya koyduğu gözlemlenmektedir. Araştırmada ölçeklerin birbirleri ile uyumlarını ortaya koyan doğrulayıcı faktör analizi sonuçları Tablo 4'te ifade edilmiştir.

Tablo 4. Doğrulayıcı Faktör Analizi Sonuçları

\begin{tabular}{|c|c|c|c|c|c|}
\hline \multicolumn{3}{|c|}{ Modeldeki İlişkilendirmeler } & Standardize $\beta$ & S.E. & $\mathbf{p}$ \\
\hline $\mathrm{CF}$ & $\longleftrightarrow$ & CR &,- 034 & ,056 & ,544 \\
\hline $\mathrm{CF}$ & $\leftrightarrow$ & SG & ,546 & ,058 & $* * *$ \\
\hline $\mathrm{CF}$ & $\longleftrightarrow$ & SD & 520 & ,058 & $* * *$ \\
\hline CR & $\longleftrightarrow$ & SG &,- 162 & ,056 & ,005 \\
\hline CR & $\longleftrightarrow$ & SD &,- 139 & ,061 & ,013 \\
\hline SG & $\longleftrightarrow$ & SD & ,568 & ,051 & $* * *$ \\
\hline
\end{tabular}

Araştırmada uygulanan DFA sonuçları dikkate alındığında çevrimiçi faydalar ve çevrimiçi riskler arasında anlamsız bir ilişki olduğu gözlemlenmektedir. Diğer değişkenlerin tamamında $p$ değeri anlamlı değişkenlere sahiptir. Çalışmada tüketicileri satın aldıkları ürünlerde çevrimiçi olmalarının faydaları, çevrimiçi olmalarının riskleri, siteye güven ve sitenin tüketici açısından değerini incelemek için bütün olarak açımlayıcı faktör analizi (AFA) ve güvenirlik analizi gerçekleştirilmiştir. Araştırmanın tamamına ilişkin AFA ve güvenirlik analizi sonuçları Tablo 5'te ifade edilmiş ve elde edilen sonuçlar literatür yardımı ile yorumlanmıştır. 
Tablo 5. AFA ve Güvenilirlik Analizi Sonuçları

\begin{tabular}{|c|c|c|c|c|c|}
\hline & Faktörler/Ifadeler & $\begin{array}{c}\text { Alpha } \\
\text { (Yüzde) }\end{array}$ & $\begin{array}{c}\text { Açıklanan } \\
\text { Varyans (\%) }\end{array}$ & Özdeğer & $\begin{array}{l}\text { Faktör } \\
\text { Yükleri }\end{array}$ \\
\hline Fakti & I 1: CF & & & & \\
\hline CF1 & Sitede satın alacağım ürünleri kolaylıkla seçebilirim & & & & 801 \\
\hline CF2 & $\begin{array}{l}\text { Sitede satın alacağım ürünleri istediğim zaman } \\
\text { seçebilirim. }\end{array}$ & $\begin{array}{c}938 \\
(\% 93,8)\end{array}$ & 45,473 & 3,958 & ,814 \\
\hline CF3 & $\begin{array}{l}\begin{array}{l}\text { Firmaya gitmeden ürünleri siteden çevrimiçi } \\
\text { seçebilirim. }\end{array} \\
\end{array}$ & & & & 830 \\
\hline CF4 & Sitedeki ürünleri kolaylıkla seçebilirim. & & & & 872 \\
\hline Faktì & I 2: CR & & & & \\
\hline CR1 & $\begin{array}{l}\text { Kredi kartı (Bankamatik) bilgilerimi web üzerinden } \\
\text { girmem güvenli değildir. }\end{array}$ & & & & ,777 \\
\hline CR2 & Web sitesine güven eksikliğim var. & & & & ,778 \\
\hline CR3 & $\begin{array}{l}\text { Kredi kartı (Bankamatik) bilgilerimi web'e girmekte } \\
\text { tereddüt ederim. }\end{array}$ & $\begin{array}{c}, 876 \\
(\% 87,6)\end{array}$ & 16,336 & 3,870 & 883 \\
\hline CR4 & $\begin{array}{l}\text { Birinin kredi kartı (Bankamatik) bilgilerini web } \\
\text { tabanlı satıcılara vermesi risklidir. }\end{array}$ & & & & 811 \\
\hline CR5 & $\begin{array}{l}\text { İsmim, adresim ve telefon numaram gibi kişisel } \\
\text { bilgilerimi internete girmekte tereddüt ederim. }\end{array}$ & & & & 815 \\
\hline Faktì & r 3: SG & & & & \\
\hline SG1 & Bu web sitesi benim için daha güvenilirdir. & & & & ,764 \\
\hline SG2 & $\begin{array}{l}\text { Bu siteye kişisel bilgilerimi gönderirken kendimi } \\
\text { güvende hissederim. }\end{array}$ & & & & 808 \\
\hline SG3 & $\begin{array}{l}\text { Bu sitede verilen bilgilerin doğruluğuna inancım } \\
\text { yüksektir. }\end{array}$ & $\begin{array}{c}, 917 \\
(\% 91,7)\end{array}$ & 7,106 & 3,664 & ,780 \\
\hline SG4 & Bu web sitesinde gizliliğim korunur. & & & & ,730 \\
\hline SG5 & $\begin{array}{l}\text { Bu sitede geçmişte satıcı ile olan deneyimime } \\
\text { dayanarak, dürüst olduğunu biliyorum. }\end{array}$ & & & & 723 \\
\hline Faktö & i: SD & & & & \\
\hline SD1 & Kendimi ürün aldığım bu siteye sadık görürüm. & & & & ,786 \\
\hline SD2 & Bu sitede satılan ürünler ilk tercihimdir. & & & & 848 \\
\hline SD3 & Bu sitenin ürünlerinin farkındayım. & ,906 & & & 669 \\
\hline SD4 & Bu sitenin özellikleri hızlıca aklıma gelir. & $(\% 90,6)$ & 5,457 & 3.388 & 662 \\
\hline SD5 & Bu sitenin işlevselliği oldukça yüksektir. & & & & 629 \\
\hline SD6 & Bu web sitesini arkadaşlarıma tavsiye etmek isterim. & & & & 605 \\
\hline KMO & $=, 913 \quad$ Bartlett's Test $=4960,507$ & $\mathrm{Al}$ & & 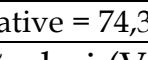 & \\
\hline
\end{tabular}

Araştırma ölçeğinde iç tutarlılık oranını ortaya koyan Cronbach-Alpha değerleri (Vazquez vd., 2013: 234) Tablo 5'te incelendiğinde ölçeğin tamamının güvenirliğini ortaya koyan CronbachAlpha=,874 olarak ve ölçeğin örneklem yeterliliğini ifade eden $\mathrm{KMO}=, 913$ olarak hesaplanmıştır. Çalışma ölçeğinde yer alan ürünlerde siteye güvenin (SG) Cronbach Alpha=,917 çevrimiçi faydaları (CF) Cronbach Alpha=,938 çevrimiçi riskleri (CR) Cronbach Alpha=,876 ve sitenin değerini ortaya koyan Cronbach Alpha=,906 değerleri bulunmuştur. Araştırmada her bir ölçeğin $\mathrm{KMO}(\mathrm{CF}=, 845$, $\mathrm{CR}=, 844, \mathrm{SG}=, 874, \mathrm{SD}=, 857)$ ve ayrı ayrı açıllanan varyans değerleri sırası ile $(\mathrm{CF}=84,479$, $\mathrm{SG}=75,504, \mathrm{SD}=69,148$ ve $\mathrm{CR}=66,884)$ olarak hesaplanmıştır. Uygulanan çalışmada dört faktörün açıklanan varyansa toplam katkısı 74,372 olarak elde edilmiştir. Araştırmanın anlamlılığını ifade eden $p$ (sig.) $=0.000$ olduğu gözlemlenmiştir. Araştırmada kullanılan ölçeklerin tamamı literatürde kabul edilen değer aralıklarına sahip olup güvenilir sonuçlar ortaya koyduğu görülmektedir (Belanger vd., 2002: 257-258; Hsu, 2008: 170). Araştırmada bütün ölçeklerin ayrı ayrı geçerli ve güvenilir sonuçlar ortaya koyduğu gözlemlenmiştir.

Araştırma faktör yükleri açısından değerlendirildiğinde; tüketicilerin çevrimiçi fayda ölçeğine en fazla katkıyı CF4 $(, 872)$ seçeneği sağlamıştır. Tüketicilerin çevrimiçi riskleri ölçeğinde en fazla katkıyı CR3 (,883) sağlamıştır. Tüketicilerin siteye güvenleri açısından bakıldığında en fazla katkıyı SG2 $(, 808)$ seçeneği sağlamıştır. Nihai olarak tüketicilerin gözünde sitenin değeri ölçeğinde en fazla katkıyı SD2 $(, 848)$ seçeneği sağlamıştır.

\subsubsection{Araştırmanın Birinci Model (Düzenleyici) Sonuçları}

Hayes oluşturduğu birinci modele ilişkin araştırmasında bağımsız değişkenin bağımlı değişken üzerinde iki koşullu etkisinin istatistiksel olarak karşılaştırılabileceğini vurgulamıştır. $\mathrm{O}$ bu 
değişkenlerin ölçümünde bağımlı $(\mathrm{Y})$, bağımsız $(\mathrm{X})$ ve moderator $(\mathrm{W})$ etkilerin araştırılabileceğini belirtmiştir (Hayes, 2018: 572). Araştırma birinci modeline ilişkin analiz sonucu aşağıdaki gibidir.

Tablo 6. Birinci (Düzenleyici) Model Sonuçları

\begin{tabular}{|c|c|c|c|c|c|c|}
\hline $\mathbf{R}$ & R-sq & MSE & $F$ & df1 & df2 & $\mathbf{P}$ \\
\hline .6982 & .4875 & .3994 & 96.3929 & 3.0000 & 304.0000 & 0.0000 \\
\hline \multicolumn{7}{|l|}{ Model } \\
\hline & Coeff & SE & $t$ & $p$ & LLCI & ULCI \\
\hline Constant & 4.0082 & .0361 & 111.1307 & .0000 & 3.9372 & 4.0792 \\
\hline ZCFo & .5832 & .0361 & 16.1352 & .0000 & .5121 & .6543 \\
\hline ZSCo01 & -.1509 & .0365 & -4.1383 & .0000 & -.2227 & -.0792 \\
\hline \multirow[t]{2}{*}{ Int_1 } & .1080 & .0350 & 3.0868 & .0022 & .0391 & .1768 \\
\hline & R2-chng & & $F$ & df1 & df2 & $\mathbf{P}$ \\
\hline $\mathbf{X}^{*} \mathbf{W}$ & .0161 & & 9.5283 & 1.0000 & 304.000 & .0022 \\
\hline ZSCo01 & Etki & SE & $t$ & $p$ & LLCI & ULCI \\
\hline-1.0436 & .4705 & .0506 & 9.2937 & .0000 & .3709 & .5701 \\
\hline .0528 & .5889 & .0362 & 16.2477 & .0000 & .5176 & .6602 \\
\hline 1.1492 & .7073 & .0548 & 12.8980 & .0000 & .5994 & .8152 \\
\hline
\end{tabular}

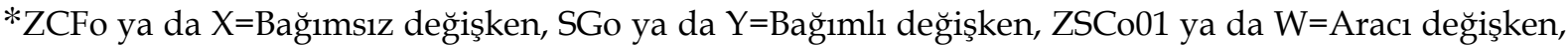
Int_1 (ZCFo*ZSCo01)=Bütünsel Moderatör etki, Effect=Etki, p $<0.05$ (anlamlılık düzeyi), LLCI=\%95 güven aralığının alt sınırı, ULCI=\%95 güven aralığının üst sınırı, Örneklem Büyüklüğü=308.

Tablo 6'da elde edilen sonuçlar dikkate alındığında birinci modelin genel olarak anlamlı ( $\mathrm{p}=.0000)$ ve değişimleri açıkladığ $\left(\mathrm{R}^{2}=.4875\right)$ ifade edilebilir. Araştırmada ZCFo, ZSCo01 ve Int_1 ilişkin sonuçlar değerlendirmeye alındığında bütün etkilerin anlamlı olduğunu ve bütünsel olarak (Int_1 ) moderatör (düzenleyici) etkiye sahip olduğu gözlemlenmektedir. Araştırmada bağımsız (CF, $\mathrm{X})$ değişken ile düzenleyici $(\mathrm{CR}, \mathrm{W})$ değişkenlerin SG üzerindeki bütüncül etkileri de anlamlı $\left(\mathrm{p}=0.0022,\left(\mathrm{R}^{2}=.0161\right)\right.$ sonuçlar ortaya koymuştur. Araştırmada moderatör etkili (çevrimiçi risk) sonuç dikkate alındığında (ZSCo01 veya CR değişkeni), çevrimiçi risk düşük olduğunda çevrimiçi faydanın siteye olan güven üzerindeki etkisi orta derecede $(.4705)$ ve anlamlı $(p=.0000)$ olduğu görülmektedir. Araştırmada çevrimiçi risk orta düzeye geldiğinde çevrimiçi faydanın siteye olan güven üzerindeki etkisi (.5889) daha da artmış ve anlamlı $(\mathrm{p}=.0000)$ bir sonuç vermiştir. Uygulamada çevrimiçi risk yüksek seviyede olduğunda ise çevrimiçi fayda algısının siteye olan güven üzerindeki etkisi çok daha fazla artmış (.7073) ve anlamlı $(\mathrm{p}=.0000)$ sonuçlar ortaya koymuştur. Bu durum tüketicilerin online alı̧̧verişlerde algıladıkları riskler ne kadar yüksek olur ise, algıladığı faydanın siteye olan güveni üzerinde o kadar çok pozitif ve anlamlı etki oluşturduğunu göstermektedir. Elde edilen sonuç fayda ve siteye güven ilişkisinde riskin düzenleyici etkisi olduğunu ve H1 hipotezinin kabul edildiğini ortaya koymaktadır. Elde edilen sonuç Grafik 1'de aşağıdaki gibi ifade edilebilir. 


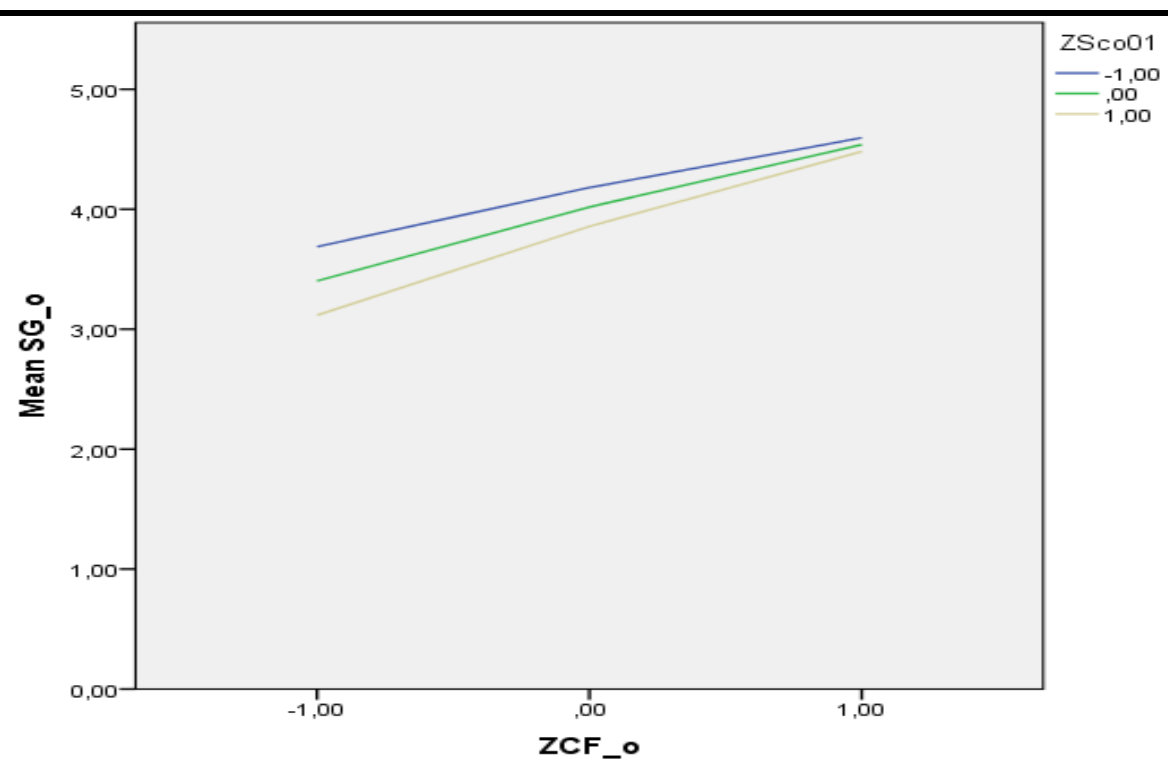

Grafik 1. Birinci Model Analiz Sonucu

Grafik 1'de elde edilen sonuç dikkate alındığında doğrusal bir ilişki olduğu gözlemlenmektedir. Yani çevrimiçi risk alt seviyede olduğunda algılanan faydanın siteye olan güven üzerinde etkili olduğu, risk orta seviyede olduğunda algılanan faydanın siteye olan güven üzerindeki etkisi arttığı ve risk en üst düzeyde olduğunda ise algılanan fayda siteye olan güveni daha fazla etkilediği gözlemlenmektedir. Bu sonuçlar web sitelerinden hazır giyim ürünü satın alan tüketicilerin sitelere olan güvenlerinin çevrimiçi algıladıkları faydayı ve riskleri ne düzeyde etkilediğini ortaya koymaktadir.

\subsubsection{Araştırmanın İkinci (Direkt Etkili) Model Sonuçları}

Gerçekleştirilen araştırmanın ikinci modelini test etmek için AMOS programı kullanılmış olup Yapısal Eşitlik Modeli sonuçları aşağıda Şekil-3 ve Tablo 7' de gösterilmiştir.

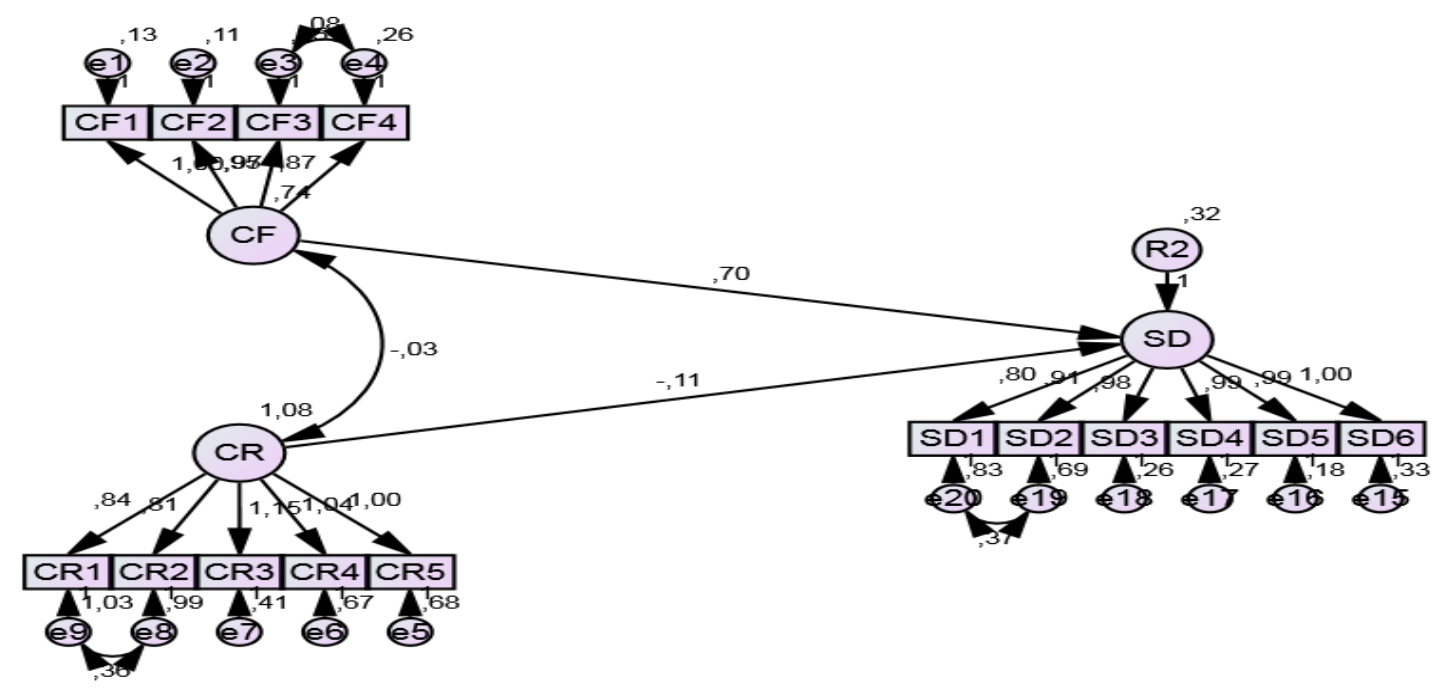

\section{Şekil 3. İkinci Model Analiz Sonucu}

Araştırma Şekil 3'te modelin tam anlamı ile uyumlu olmasını sağlayabilmek için CF3-CF4, CR1CR2 ve SD1-SD2 maddeleri arasında modifikasyon gerçekleştirilmiştir. Şekil 3'te elde edilen bulgular incelendiğinde tüketicilerin hazır giyim ürünü satın alırken kullandıkları sitelere yönelik algıladıkları çevrimiçi faydaların sitenin tüketici gözündeki değerini güçlü bir şekilde pozitif ve anlamlı olarak etkilediği anlaşılmaktadır. Ayrıca tüketicilerin algıladıkları çevrimiçi risklerin ise sitenin tüketici bakış açısındaki değerini olumsuz ve anlamlı olarak etkilediği gözlemlenmiştir. 
Tablo 7. İkinci Modelin Uyum İyiliği Sonuçları

\begin{tabular}{|c|c|c|c|c|c|c|c|c|}
\hline İndeksler & CMIN/DF & RMR & IFI & GFI & CFI & TLI & RMSEA & Kaynak \\
\hline İndeks Değerleri & $<3.00$ & $<0.08$ & $>0.9$ & $>0.9$ & $>0.9$ & $>0.9$ & $<0.08$ & $\begin{array}{c}\text { Chakraborty ve } \\
\text { Chechi, 2020: 5896 }\end{array}$ \\
\hline Araştırma Sonucu & 2.701 & .057 & .959 & .917 & .958 & .948 & .074 & Uyumlu \\
\hline
\end{tabular}

İkinci modele ilişkin Yapısal Eşitlik Modeli (YEM) sonuçları genel itibari ile değerlendirildiğinde RMSEA değeri $(\operatorname{RMSEA}=, 074)$ kabul edilebilir bir veri uyumu olduğunu ortaya koymaktadır. Çalışmada GFI değeri (GFI=,917), IFI değeri (IFI=,959), CFI değeri (CFI=,958) ve NFI değerleri $(\mathrm{NFI}=, 936)$ elde edilmiştir. Bu sonuçlar araştırma modelinin kabul edilebilir ve uyumlu değerlere sahip olduğunu göstermektedir (Wakefield vd., 2004: 97).

Tablo 8. İkinci Model (Direkt Etkili) Uygulama Sonuçları

\begin{tabular}{|c|c|c|c|c|c|c|}
\hline Modeldeki İlişkilendirmeler & Standardize $\boldsymbol{\beta}$ & $\mathbf{S . E .}$ & $\mathbf{p}$ & Hipotez & Açıklama \\
\hline $\mathrm{CR} \rightarrow \mathrm{SD}$ &,- 106 &, 037 &, $\mathbf{0 0 5}$ & $\mathrm{H} 2$ & Kabul \\
\hline $\mathrm{CF} \rightarrow \mathrm{SD}$ &, 699 &, 053 & $* * *$ & H3 & Kabul \\
\hline
\end{tabular}

Tablo 8'de elde edilen sonuçlar incelendiğinde; tüketicilerin algıladıkları çevrimiçi risklerin sitenin tüketici gözündeki değerini negatif $(-, 106)$ ve $(p=, 005)$ anlamlı olarak etkilediği sonucuna ulaşılmıştır. Ayrıca tüketicilerin çevrimiçi algıladıkları faydaların sitenin tüketicinin gözündeki değerini pozitif $(, 699)$ ve anlamlı $(p=, 000)$ olarak etkilediği görülmüştür. Bu sonuçlar H2 ve H3 hipotezleri kabul edildiğini ortaya koymaktadır.

\subsubsection{Araştırmanın Üçüncü (Aracı) Model Sonuçları}

Araştırmanın üçüncü modelini test etmek için AMOS programından faydalanılmış olup yapısal eşitlik modeli sonuçları Şekil-4 ve Tablo 9'da ortaya koyulmuştur. Literatürde aracı değişken, sonuç değişkenine katkıda bulunan iki nedensel yol ile üç değişkenli bir sistemin var olduğu vurgulanmaktadır. Bu değişkenlerde bağımsız değişkenin doğrudan etkisi (CF-SD ve CR-SD yolu), bağımsız değişkenden aracı değişkene doğru bir yol (CF-SG ve CR-SG yolu) ve aracı değişkenin etkisi (SG-SD yolu) şeklinde analiz edilmektedir (Baron ve Kenny, 1986: 1176). İlgili analiz sonuçları aşağıdaki belirtilmiştir.

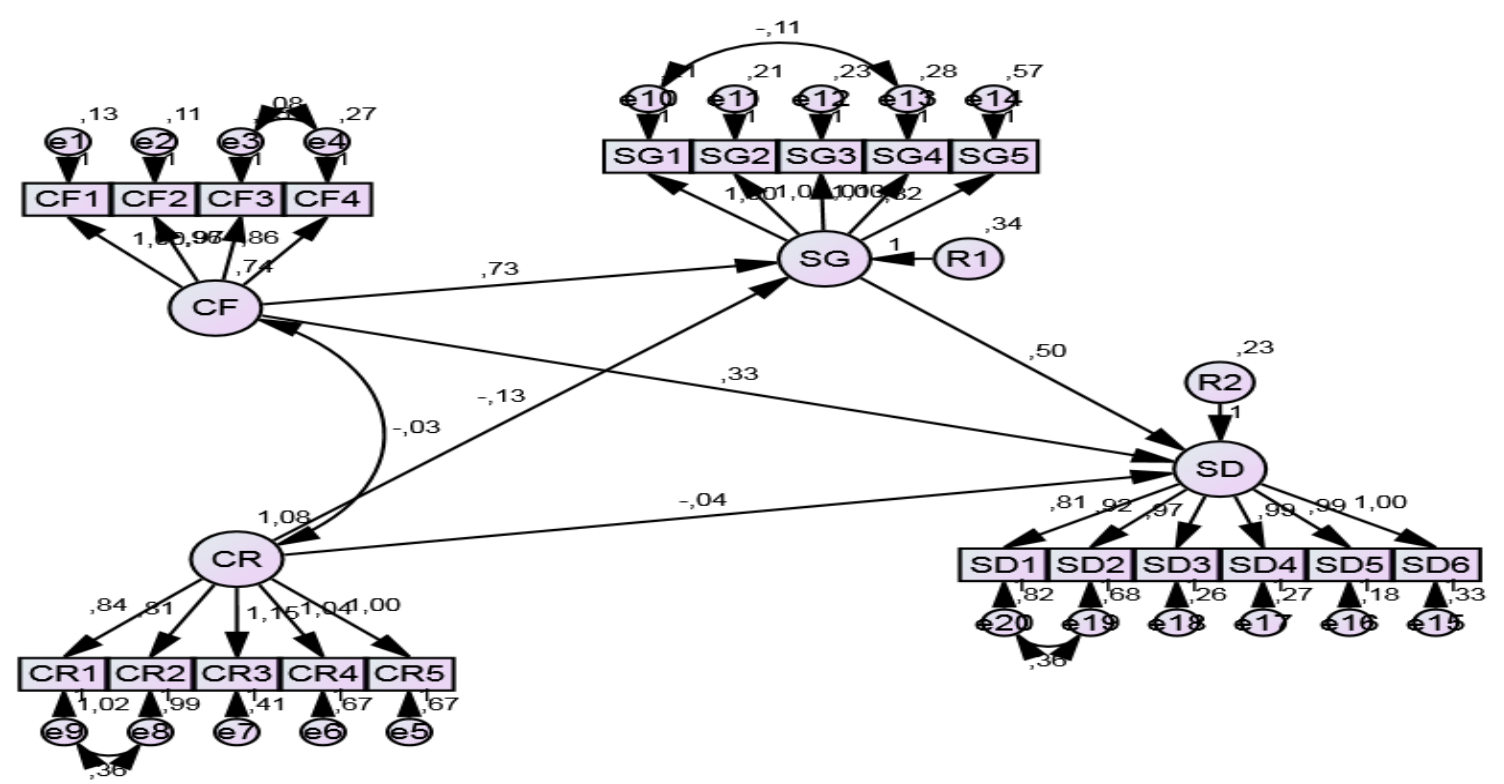

\section{Şekil 4. Üçüncü Model Analiz Sonucu}

Araştırma Şekil 4'te elde edilen sonuçlar genel itibari ile değerlendirildiğinde; çalışma hipotezlerinden $\mathrm{H} 4, \mathrm{H} 5, \mathrm{H} 6, \mathrm{H} 7$ ve $\mathrm{H} 8$ hipotezleri kabul edilmiştir. Bu sonuçlara göre $\mathrm{H} 4$ hipotezinde web sitelerinden hazır giyim ürünü satın alan tüketicilerin çevrimiçi olmalarının riskleri siteye olan güvenlerini negatif (,-13) ve anlamlı olarak etkilemiştir. H5 hipotezinde ise tüketicilerin 
web sitesine yönelik algıladıkları çevrimiçi risklerin sitenin değeri üzerindeki etkisinde siteye olan güvenlerinin tam aracı $(-, 04)$ etkiye sahip olduğu gözlemlenmiştir. Bu sonuç bağımsız değişkenin (CR) bağımlı değişken (SD) üzerindeki dolaylı etkisinde aracı değişkenin (SG) önemli olduğunu ortaya koymaktadır. H6 hipotezinde web sitelerinden hazır giyim ürünü satın alan tüketicilerin çevrimiçi olmalarının faydalarının siteye olan güvenlerini pozitif yönde $(, 73)$ ve anlamlı olarak etkilemiştir. H7 hipotezinde tüketicilerin çevrimiçi faydalarının sitenin değeri üzerindeki etkisinde siteye olan güvenlerinin kısmi aracı etkiye sahip olduğu gözlemlenmiştir. H8 hipotezinde ise web sitelerinden hazır giyim ürünü satın alan tüketicilerin siteye olan güvenleri sitenin onların gözündeki değerini pozitif $(, 50)$ ve anlamlı yönde etkilemiştir. Araştırma modelinde uyum değerlerini optimal seviyeye taşıyabilmek için CF3-CF4, CR1-CR2, SG1-SG4 ve SD1-SD2 maddeleri arasında modifikasyon gerçekleştirilmiştir.

Tablo 9. Üçüncü Modelin Uyum İyiliği Sonuçları

\begin{tabular}{|c|c|c|c|c|c|c|c|c|}
\hline İndeksler & CMIN/DF & RMR & IFI & GFI & CFI & TLI & RMSEA & Kaynak \\
\hline İndeks Değerleri & $<3.00$ & $<0.08$ & $>0.9$ & $>0.9$ & $>0.9$ & $>0.9$ & $<0.08$ & $\begin{array}{c}\text { Chakraborty ve } \\
\text { Chechi, 2020: 5896 }\end{array}$ \\
\hline Araştırma Sonucu & 2.144 & 0.54 & .963 & .907 & .963 & 956 & .061 & Uyumlu \\
\hline
\end{tabular}

Üçüncü modelin yapısal eşitlik modeli (YEM) sonuçları genel itibari ile değerlendirildiğinde RMSEA değeri (RMSEA $=$,061) kabul edilebilir bir veri uyumuna sahip olduğu görülmektedir. Araştırmada GFI değeri (GFI=,907), IFI değeri $(\mathrm{IFI}=, 963)$, CFI değeri $(\mathrm{CFI}=, 963)$ ve NFI değerleri $(\mathrm{NFI}=, 933)$ literatürde kabul edilebilir değer aralıklarına sahip olduğu gözlemlenmiştir.

Tablo 10. Üçüncü (Aracı) Model Uygulama Sonuçları

\begin{tabular}{|cc|r|c|c|c|c|}
\hline \multicolumn{2}{|c|}{ Modeldeki İlişkilendirmeler } & Standardize $\boldsymbol{\beta}$ & $\mathbf{S . E .}$ & $\mathbf{p}$ & Hipotez & Açıklama \\
\hline $\mathrm{CR}$ & $\rightarrow$ SG &,- 126 &, 038 & ${ }^{* * *}$ & H4 & Kabul \\
\hline$(\mathrm{SG}$ arac1) CR $\rightarrow$ SD &,- 043 &, 033 & ${ }^{202}$ & H5 & Kabul \\
\hline CF $\rightarrow$ SG &, 733 &, 051 & ${ }^{* * *}$ & H6 & Kabul \\
\hline$($ SG arac1) CF $\rightarrow$ SD &, 328 &, 061 & ${ }^{* * *}$ & H7 & Kabul \\
\hline SG $\rightarrow$ SD &, 504 &, 065 & ${ }^{* * *}$ & H8 & Kabul \\
\hline
\end{tabular}

Tablo 10'da elde edilen sonuçlar incelendiğinde; CR'nin SG üzerinde negatif $(-, 126)$ ve anlamlı $(\mathrm{p}=, 000)$ etkisi olduğu gözlemlenmektedir (H4 kabul). CR'nin SD üzerindeki etkisinde SG tam arac1 ( $p=, 202$ anlamsız ve Standardize $\beta=-, 043^{\prime}$ e düştüğü için) etkiye sahip olmuştur (H5 kabul). CF'nin SG üzerinde güçlü pozitif $(, 733)$ ve anlamlı $(p=, 000)$ etkisi olduğu görülmektedir (H6 kabul). CF'nin SD üzerindeki etkisinde SG tam aracı etkiye $(p=, 000)$ sahip olmamıştır. Ancak bu hipotez Baron ve Kenny'nin (1986: 1176) araştırmalarına göre kısmi aracı ( $\beta=, 328^{\prime}$ düşmüştür) etkiye sahiptir. Dolayısı ile hipotez geçerlidir (H7 Kabul). SG'nin SD üzerinde güçlü pozitif $(, 504)$ ve anlamlı $(p=, 000)$ etkisi olduğu görülmüştür (H8 kabul). Model 3'e ilişkin literatür indeksleri ve elde edilen değerler Tablo 10 'da ifade edilmiştir.

\section{Sonuç ve Değerlendirme}

Günümüzde hızlı bir şekilde değişen, gelişen ve çeşitlilik gösteren hazır giyim ürünlerinde firmalar farklı veya benzer reklam stratejileri ile tüketicilere ürünlerini pazarlamaktadırlar. Firmalar/markalar bu ürünlerini pazarlarken kendi web sitelerini veya farklı siteleri kullanabilmektedirler. Bu açıdan tüketicileri bu ürünlere yönlendirebilecek farklı reklam araçları bulunmaktadır. Araştırma sonuçlarında elde edilen veriler tüketicilerin tercih sıralarına göre trendyol, lcw, diğer siteler, hepsiburada, koton, defacto, gittigidiyor, boyner, mavijeans, collezione, alibaba web sitelerinden alışveriş yaptıklarını ifade etmişlerdir. Tüketicilerin bu web sitelerini tercih ederken etkilendikleri reklam araçları sırası ile çevresindeki bireyler, internet reklamları, televizyon reklamları, dergi reklamları ve gazete reklamları şeklinde sıralanmışlardır. Reklam aracı tercihine yönelik bulgu Durmuş ve Battal'ın (2018) çalışmalarında elde ettikleri sonucu desteklemektedir. Sonuçlar hazır giyim ürünü satın alan bireylerin en fazla çevresindeki kişilerden etkilendiklerini 
belirtmişlerdir. Ayrıca günümüzde değişen ve gelişen teknolojik yeniliklere bağlı olarak internet reklamlarının da web sitelerinden hazır giyim ürünü almakta oldukça etkili olduğunu göstermektedir.

Araştırmada tüketiciler tercih ettikleri sitelerdeki ürünleri kolaylıkla seçebildiklerini ifade etmişlerdir. Tüketiciler kredi kartı veya bankamatik bilgilerini web sitelerin'e girmekte tereddüt etmediklerini belirtmişlerdir. Ayrıca tüketiciler alışveriş yaptıkları web sitesine kişisel bilgilerini gönderirken kendilerini güvende hissettiklerini vurgulamışlardır. Tüketicilerin hazır giyim ürünü satın aldıkları web sitelerinde satılan ürünlerin ilk tercihleri olduğunu açıklamışlardır.

Araştırma sonuçları genel olarak dikkate alındığında; tüketicilerin web sitelerine yönelik çevrimiçi fayda algılarının siteye güvenleri üzerindeki etkisinde çevrimiçi riskler düzenleyici etkisi bulunmuştur. Tüketicilerin alışveriş yaptıkları sitelerden algıladıkları çevrimiçi faydaların sitenin tüketici gözündeki değerinin artmasına yol açmıştır. Tüketicilerin alışveriş yaptıkları sitelerden algıladıkları çevrimiçi risklerin ise sitenin tüketici gözündeki değerinin azalmasına neden olmuştur. Araştırmada tüketicilerin alışveriş yaptıkları sitelerden algıladıkları çevrimiçi faydalar siteye olan güvenin artmasını sağlamıştır. Tüketicilerin alışveriş yaptıkları sitelerden algıladıkları çevrimiçi riskler ise siteye olan güvenin azalmasına sebep olmuştur. Araştırmada tüketicilerin alışveriş yaptıkları sitelerden algıladıkları çevrimiçi risklerin sitenin değeri üzerindeki etkisinde siteye olan güvenin aracılık rolü tespit edilmiştir. Tüketicilerin alışveriş yaptıkları sitelerden algıladıkları çevrimiçi faydaların sitenin değeri üzerindeki etkisinde siteye güvenin kısmi aracılık rolü olduğu gözlemlenmiştir. Son olarak tüketicilerin alışveriş yaptıkları sitelere olan güvenleri sitenin tüketicinin gözündeki değerinin artmasına katkıda bulunmuştur.

Çevrimiçi faydalar ve çevrimiçi risklerin sitenin değeri üzerindeki etkileri incelendiğinde; Sheehan ve Hoy (2000) çevrimiçi olmada beş temel ilkeye, bunların; uyarı, seçim, erişim, güvenlik ve düzeltme olduğunu ve bu değişkenlere dikkat edilmesi gerektiğini vurgulamışlardır. Tsai ve diğerleri (2011) çevrimiçi alışverişlerde tüketicilerin gizlilik bilgilerinin korunmasının önemli olduğunu vurgulamışlardır. Ghandour (2015) sitenin tüketici gözünde değerli olabilmesi için hedef belirleme, web sitesi, pazarlama ve internet güvenliği gibi etmenler ile web sitesinin rakip olarak değerlendirdiği web sitelerinden farklı olduğu yönlerini ortaya koyabilmesi gerektiğini ifade etmiştir. Oyeyemi ve diğerleri (2018) daha önce deneyimi olmayan bireylerde çevrimiçi davranışlarının riskli olabileceğini ifade etmişlerdir. Araştırma sonuçlarında çevrimiçi faydaların sitenin değeri üzerinde pozitif, çevrimiçi risklerin ise negatif etkilerinin olduğu sonuçlarına ulaşılmıştır. Bu sonuçlar uyarı, tercih, erişim, güvenlik, düzeltme, gizlilik bilgilerinin korunması, hedef belirleme, pazarlama, güven ve deneyim kavramlarının etkili olabileceğini desteklemektedir.

Çevrimiçi faydalar ve web sitesine güven açısından bakıldığında; Shanker ve diğerleri (2002) çevrimiçi faydalarda güvenin önemli olduğunu zira kalite, yardımseverlik ve duygusal rahatlık verdiğini ifade etmişlerdir. Zhou ve diğerleri (2007) çevrimiçi alışverişlerde olumlu duyguların çevrimiçi alışverişi olumlu yönde etkilediğini tespit etmişlerdir. Hsu (2008) tüketicilerin çevrimiçi olmalarında çevrimiçi güven faktörlerinin (marka, itibar, kalite, sistem gibi) önemli olduğunu vurgulamıştır. Öztüren (2013) ise çevrimiçi sosyal ağlarda yetkinlik, öngörülebilirlik, bütünlük ve yardımseverlik algılarının tüketicilerin çevrimiçi güven duygularını artırdığını ifade etmiştir. Araştırmada tüketicilerin web sitelerinden algıladıkları çevrimiçi fayda düzeylerinin siteye olan güvenlerini pozitif olarak etkilediğini saptamışlardır. Bu durumda tüketiciler, çevrimiçi güven faktörlerini ve çevrimiçi alışverişi olumlu olarak algılayabildiklerler. Ayrıca araştırma sonuçları ile tüketicilerin siteye olan güvenlerinin onlarda duygusal rahatlık, yardımseverlik ve bütünlük ile ilgili öngörülebilir pozitif sonuçlar oluşturabileceğini akıllara getirebilmektedir.

Çevrimiçi riskler ve siteye güven açısından bakıldığında; McKnight ve diğerleri (2002b) çevrimiçi alışverişlerde güven veya güvensizlik faktörlerinde inanç kavramının önemli olduğunu, Ahuja ve diğerleri (2003) güven ve gizlilik endişelerinin çevrimiçi alışverişlerde en büyük engellerin olduğunu, Martin ve Camarero (2008) deneyimin yanı sıra motive olmuş bireylerin web sitesince sunulan hizmet kalitesine değer verdiklerini ve bu durumun güveni artırdığını, Zhu ve diğerleri (2011) ise siteye olan güvenin çevrimiçi riskleri azalttı̆̆ını ifade etmişlerdir. Araştırmada tüketicilerin tercih ettikleri web sitesine yönelik çevrimiçi risklerinin siteye olan güveni negatif 
yönde etkilediği görülmektedir. Bu durum tüketicilerin web sitelerini riskli görmediklerini, web sitesi tarafından motive olmuş olabileceklerini dolayısı ile web sitesine yönelik güven duygusuna sahip olduklarını göstermektedir. Bu sonuçlar tüketicilerin web sitesine yönelik daha önceki deneyimlerinden veya web sitesinde gizlilik bilgilerinin korunmasından kaynaklanabilir.

Çevrimiçi faydalar, çevrimiçi riskler, siteye güven ve tüketicilerin gözünde sitenin değeri açısından incelendiğinde ise; Hampton-Sosa ve Koufaris (2005) gelecekte web sitesini kullanma niyetinde algıların ve güvenin önemli unsurlar olduğunu ifade etmişlerdir. Park ve Kim (2008) ise tüketici gözünde sitenin ne kadar değerli olabileceğini bu sitelerin (firmaların) uyguladıkları politika ve stratejilerin (bilgi memnuniyeti, ilişkisel fayda, ürün-hizmet kalitesi, güven algısı) önemli olduğunu belirtmişlerdir. Araştırma sonuçlarında tüketicilerin hazır giyim ürünü satın aldıkları web sitelerine güven duygularının sitenin tüketici gözündeki değerini pozitif yönde etkilediğini ortaya koymaktadır. Ayrıca tüketicilerin algıladıkları çevrimiçi risklerin sitenin değeri üzerindeki etkisinde siteye olan güvenlerinin tam aracı etkiye sahip olduğu gözlemlenmiştir. Bu sonuçlar tüketicilerin genel olarak bu sitelerde bilgi memnuniyeti, faydalı ilişki, kaliteli ürün ve hizmet, olumlu algı ve güven gibi etmenler ile oluşan olumlu izlenim tüketicilerin gözünde sitenin değerli olmasını sağlamış olabilir.

Sonuç olarak çevrimiçi fayda düzeyinin siteye olan güven üzerindeki etkisi artıkça çevrimçi içi riskin de düzenleyici etkisinin arttı̆̆ı gözlemlenmiştir. Aracılık ilişkisi açısından değerlendirildiğinde, çevrimiçi risklerin sitenin değeri üzerindeki etkisinde siteye olan güven tam aracı etkiye sahip olmuştur. Çevrimiçi faydanın sitenin değeri üzerindeki etkisinde ise siteye güven kısmi aracı etkisi olduğu gözlemlenmiştir. Bu sonuçlar ise sitenin değeri açısından, fayda ve risk algısında, risk algısının siteye güven değişkenin tam aracılık etmesinde daha etkili olduğunu göstermektedir. Bu durum, tüketicilerin risk algılarının sitenin değeri üzerindeki etkisinde güven mekanizmasının oldukça önemli olduğunu ortaya koymaktadır. Sonuçlar genel olarak değerlendirildiğinde web sitelerinden hazır giyim ürünü satın alan tüketiciler çevrimiçi alışverişleri faydalı görmekte, çevrimiçi alışverişi riskli algılamamakta, alışveriş yaptığı siteye güvenmekte ve tüketici için alışveriş yapılan siteler değerli olabilmektedir.

Araştırma sonuçları güven teorisi açısından değerlendirildiğinde; tüketicilerin çevrimiçi ürün siparişlerinde algıladıkları faydanın güven duygularına önemli katkıları olduğunu göstermektedir. Araştırmada tüketicilerin çevrimiçi ürün alışverişlerinde algıladıkları risklerin ise güven duygularını azalttığı sonucuna erişilmiştir. Araştırmada teorik çerçevede siteye olan güvenin sitenin tüketici gözündeki değerine ise önemli katkıları olduğu görülmüştür. Bu sonuçlar güven kuramı açısından tüketicilerin web sitelerinden hazır giyim ürünü satın almalarında çevrimiçi fayda, risk ve sitenin değerinin önemli etkileri olduğunu göstermektedir. Bu sonuçlar literatürde güven teorisi ile birlikte fazla araştırılmayan çevrimiçi fayda, çevrimiçi risk, siteye güven ve sitenin tüketici açısından değeri değişkenlerinin güven teorisine önemli katkıları olabileceğini göstermektedir. Wang ve diğerleri (2016) güven teorisi kapsamında tüketicilerin web sitelerinden ürün satın almalarında, elektronik ticarette sistem tasarlamanın önemli olduğunu, tüketicilerin satın alma süreçlerinde karmaşıklığ1 azaltabileceği, rahatlığı ve güveni artırarak endişelerden kaynaklanabilecek belirsizlik ve riskleri azaltabileceği ve bu durumun tüketicilerin algıladıkları değeri ve memnuniyeti artırabileceğini ifade etmişlerdir. Bu sonuçlar elektronik ticaretteki sistem tasarımı açısından araştırma sonularını desteklemektedir.

Araştırma tüketicilerin çevrimiçi fayda ve çevrimiçi risk algıları, siteye olan güvenleri ve sitenin tüketici nezdinde ki değerini kapsayacak şekilde uygulanmıştır. Bu açıdan tüketicilerin güvenlerini ve sitenin tüketici gözündeki değerini etkileyebilecek farklı etmenler de olabilir. Gelecek araştırmalarda sadece hazır giyim sektörü değil farklı sektörlerde dikkate alınabilir. Tüketicilerin bu web sitelerini tercih etmelerinde etkili olan başka faktörlerin (reklam araçları vb.) neler olabileceği incelenebilir. Ayrıca tüketicilerin çevrimiçi olmalarının faydalı veya riskli yönlerini, güven ve değer kavramlarını etkileyebilecek başka değişkenlerin (memnuniyet, sadakat, bağlılık, marka tutkusu gibi) de olabileceği dikkate alınarak araştırılabilir. Böylece literatüre yeni ve farklı bakış açıları kazandırılabilir. 


\section{Kaynakça}

Ahuja, M., Gupta, B. \& Raman, P. (2003). An empirical investigation of online consumer purchasing behavior. Communications of the ACM, 46 (12), 145-151.

Akyüz, A. M. (2014). Çevrimiçi hazır giyim ürünleri tüketiminde müşteri tatmini: Doğu Karadeniz örneği. Doğuş Üniversitesi Dergisi, 15(1), 91-108.

Baltar, F. \& Brunet, I. (2012). Social research 2.0: Virtual snowball sampling method using Facebook. Internet Research, 22(1), 57-74.

Baron, R. M. \& Kenny, D. A. (1986). The moderator-mediator variable distinction in social psychological research: Conceptual, strategic, and statistical considerations. Journal of Personality and Social Psychology, 51(6), 1173-1182.

Belanger, F., Hiller, J. S. \& Smith, W. J. (2002). Trustworthiness in electronic commerce: The role of privacy, security, and site attributes. Journal of Strategic Information Systems, 11, 245-270.

Biernacki, P. \& Waldorf, D. (1981). Snowball sampling: Problems and techniques of chain referral sampling. Sociological Methods \& Research, 10(2), 141-163.

Castelfranchi, C. \& Falcone, R. (2005). Socio-cognitive theory of trust. J. Pitt. London Wiley, 58-89.

Chakraborty, R. \& Chechi, V. K. (2020). Network psychometrics based validation of volitional component of self regulated learning and estimation of its polychoric ordinal omega reliability. Mukt Shabd Journal, 9(6), 5890-5909.

Chang, A., Chiang, H-H. \& Han, T. S. (2015). Invastigating the dual-route effects of corporate branding on brand equity. Asia Pacific Management Review, 20, 120-129.

Cugelman, B., Thelwall, M. \& Dawes, P. (2009). The dimensions of web site credibility and their relation to active trust and behavioural impact", Communications of The Association for Information Systems, 24(26), 453-473.

Cyr, D., Bonanni, C., Bowes, J. \& Ilsever, J. (2005). Beyond trust: Website desing preferences across cultures. Journal of Global Information Management, 13(4), 24-52.

Cyr, D. (2008). Modelingf web site desing across cultures: Relationships to trust, satisfaction, and eloyalty. Journal of Management Informatio Systems, 24(4), 47-72.

Cyr, D., Kindra, G.S. \& Dash, S. (2008). Website desing, trust, satisfaction and e-loyalty: The Indian experience", Online Information Review, 32(6), 773-790.

Delafrooz, N., Paim,L. H., Haron, S. A., Sidin, S. M. \& Khatibi, A. (2009). Factors affecting students attitude toward online shopping. African Journal of Business Management, 3(5), 200-209.

Durmuş, İ. \& Battal, F. (2018). Tüketicilerin hazır giyim tercihlerinde marka, reklam arac1, tutum ve satınalma karar verme tarzlar1. The Journal of Social Sciences Institute, (42), 199-224.

Dwyer, C., Hiltz, S. R. \& Passerini, K. (2007). Trust and privacy concern within social networking sites: A comparison of Facebook and MySpace. Americas Conference on Information Systems, 339353.

Everard, A. \& Galletta, D. F. (2005). How presentation flaws affect perceived site quality, trust, and intention to purchase from an online store. Journal of Management Information Systems, 22(3), 5695.

Friedman, B., Kahn J. R., P. H. \& Howe, D. C. (2000). Trust online. Communications of The Acm, 43(12), 34-40.

Gefen, D., Karahanna, E. \& Straub, D. W. (2003). Trust and TAM in online shopping: An integrated model. MIS Quarterly, 27(1), 51-90.

George, J. F. (2004). The theory of planned behavior and internet purchasing. Internet Research, 14(3), 198-212.

Ghandour, A. (2015). Ecommerce website value model for SMEs. International Journal of Electronic Commerce Studies, 6(2), 203-222.

Grabner-Kraeuter, S. (2002). The role of consumers trust in online-shopping. Journal of Business Ethics, 39(1-2), 43-50.

Hajli, M. N. (2013). A study of the impact of social media on consumers. International Journal of Market Research, 56(3), 387-404. 
Hampton-Sosa, W. \& Koufaris, M. (2005). The effect of web site perceptions on initial trust in the owner company. International Journal of Electronic Commerce, 10(1), 55-81.

Hann, I-H., Hui, K-L., Lee, T. \& Png, I. (2002). Online information privacy: Measuring the costbenefit trade-off. International Conference on Information Systems, 1-10.

Hayes, A. F. (2018). Introduction to mediation, moderation, and conditional process analysis. David A. Kenny and Todd D. Little (Ed.), Second Edition (ISBN: 9781462534654), The Guilford Press: New York.

Hsu, C-J. (2008). Dominant factors for online trust"', International Conference on Cyberworlds, 165-172.

Isaeva, N., Gruenewald, K. \& Saunders, M. N. K. (2020). Trust theory and customer services research: Theoretical review and synthesis. The Service Industries Journal, 40(15/16), 1031-1063.

Jong, J. T. V. M. D. \& Ommeren, M. V. (2002). Toward a culture-informed epidemiology: Combining qualitative and quantitative research in transcultural contexts. Transcultural Psychiatry, 39(4), 422-433.

Krejcie, R. V. \& Morgan, D. W. (1970). Determining sample size for research activities. Educational and Psychological Measurement, 30, 607-610.

Lin, N-P, Weng, J. C. M. \& Hsieh, Y-C. (2003). Relational bonds and customer's trust and commitment - a study on the moderating effects of web site usage. Service Industries Journal, 23(3), 103-124.

Lowry, P. B., Vance, A., Moody, G., Beckman, B. \& Read, A. (2008). Explaining and predicting the impact of branding alliances and web site quality on initial consumer trust of e-commerce web sites. Journal of Management Information Systems, 24(4), 199-224.

Loureiro, S. M. C. (2013). The effect of perceived benefits, trust, quality, brand awareness/associations and brand loyalty on internet banking brand equity. International Journal of Electronic Commerce Studies, 4(2), 139-158.

Ma, J. \& Orgun, M. (2006). Trust management and trust theory revision. IEE Transactions on Systems, Man, and Cybernetics-Part A: Systems and Humans, 36(3), 451-460.

Martin, S. S. \& Camarero, C. (2008). Consumer trust to a web site: Moderating effect of attitudes toward online shopping. Cyber Psychology \& Behavior, 11(5), 549-554.

McKnight, D. H., Kacmar, C. J. \& Choudhury, V. (2004). Dispositional trust and distrust distinctions in predicting high- and low-risk internet expert advice site perceptions. e-Service Journal, 3(2), 35-58.

McKnight, D. H., Choudhury, V. \& Kacmar, C. (2000). Trust in e-commerce vendors: A two-stage model. International Conference on Information Systems, 54, 532-536.

McKnight, D. H., Choudhury, V. \& Kacmar, C. (2002a). The impact of initial consumer trust on intentions to transact with a web site: A trust building model. Journal of Strategic Information Systems, 11, 297-323.

McKnight, D. H., Choudhury, V. \& Kacmar, C. (2002b). Developing and validating trust measures for e-commerce: An integrative typology", Information Systems Reserch, 13(3), 334-359.

Morgan, R. M. \& Hunt, S. D. (1994). The commitment-trust theory of relationship marketing. Journal of Marketing, 58, 20-38.

Mukherjee, A. \& Nath, P. (2007). Role of electronic trust in online retailing: A re-examination of the commitment-trust theory. European Journal of Marketing, 41(9/10), 1173-1202.

Oyeyemı, S. O., Kesinro, O. R. \& Morakinyo, D. A. (2018). Perceived risk and online shopping ineffectiveness in retail industry of lagos state, Nigeria. International Journal for Innovative Research in Multidisciplinary Field, 4(8), 10-17.

Öztüren, A. (2013). Effects of electronic trust on purchase intentions in online social review networks: The case of tripadvisor.com. Life Science Journal, 10(2), 2002-2010.

Park, C-H. \& Kim, Y-G. (2008). The effect of information satisfaction and relational benefit on consumer's online shopping site commitment. Web Technologies for Commerce and Services Online, 149-169.

Schlosser, A. E., Shavitt, S. \& Kanfer, A. (1999). Survey of internet users' attitudes toward internet advertising. Journal of Interactive Marketing, 13(3), 34-54. 
Shankar, V., Urban, G. L. \& Sultan, F. (2002). Online trust: A stakeholder perspective, concepts, implications, and future directions. Journal of Strategic Information Systems, 11, 325-344.

Sheehan, K. B. \& Hoy, M. G. (2000). Dimensions of privacy concern among online consumers. Journal of Public Policy \& Marketing, 19(1), 62-73.

Shergill, G. S. \& Chen, Z. (2005). Web-based shopping: Consumers attitudes towards online shopping in New Zealand", Journal of Electronic Commerce Research, 6 (2), 79-94.

Siau, K. \& Shen, Z. (2003). Building customer trust in mobile commerce. Communications of The Acm, 46(4), 91-94.

Tsai, J. Y., Egelman, S., Cranor, L. \& Acquisti, A. (2011). The effect of online privacy information on purchasing behavior: An experimental study. Information Systems Research, 22(2), 254-268.

TÜBİSAD (2021a). Bilgi ve iletişim teknolojileri sektörü, Bilişim Sanayiciler Derneği, Deloitte Danışmanlı A.Ş. (https://www.tubisad.org.tr/tr/bilgi-bankasi/sunumlar-liste/TUBISADRaporlar/40/0/0).

TÜBİSAD (2021b). Ekonominin dönüştürücü gücü: E-ticaret etki analizi. Bilişim Sanayiciler Derneği, Deloitte Danışmanlık A.Ş. (https://www.tubisad.org.tr/tr/bilgi-bankasi/sunumlarliste/TUBISAD-Raporlar/40/0/0).

Urban, G. L., Sultan, F. \& Qualls, W. J. (2000). Placing trust at the center of your internet strategy. Sloan Management Review, 42(1), 39-49.

Valenzuela, S., Park, N. \& Kee, K. F. (2009). Is there social capital in a social network site?: Facebook use and college students life satisfaction, trust, and participation. Journal of Computer-Mediated Communication, 14, 875-901.

Vazquez, M. B., Llaguno, M. M. \& Ruiz, A. H. (2013). The factor structure of the spanish version of the work-family culture scale in a sample of workers from the advertising sector. Psicothema, 25(2), 232-237.

Wakefield, R. L., Stocks, M. H. \& Wilder, W. M. (2004). The role of web site characteritics in initial trust formation", Journal of Computer Information Systems, 45(1), 94-103.

Wang, L. C., Baker, J., Wagner, J. A. \& Wakefield, K. (2007). Can a retail web site be social? Journal of Marketing, 71(3), 143-157.

Wang, W-T., Wang, Y-S., \& Liu, E-R. (2016). The stickiness intention of group-buying websites: The integration of the commitment-trust theory and e-commerce success model. Information $\mathcal{E}$ Management, 53, 625-642.

Yıldız, S. (2018), “Elektronik Hizmet Marka Değerini Etkileyen Faktörler: Elektronik Hizmet Müşterileri Üzerine Bir Uygulama", Global Journal of Economics and Business Studies, C. 7, Sy. 14, ss. 170-185.

Yıldız, S. ve Çilingir, Z. (2010), “Elektronik Pazarlamada Müşteri Sadakatinin Geliştirilmesi: Karadeniz Teknik Üniversitesi Öğrencileri Üzerine Bir Araştırma", Ç.Ü. Sosyal Bilimler Enstitüsü Dergisi, S. 1: 412-428.

Yıldız, S. \& Kırmızıbiber, A. (2020). Kişilik özellikleri ile güven ve risk arasındaki ilişki: E-ticaret müşterileri üzerine bir uygulama. Gümüşhane Üniversitesi Sosyal Bilimler Enstitüsü Elektronik Dergisi, 11(2), 494-507.

Zhou, L., Dai, L. \& Zhang, D. (2007). Online shopping acceptance model a critical survey to consumer factors in online shopping. Journal of Electronic Commerce Research, 8(1), 41-62.

Zhu, D. S., Lee, Z. C., O'Neal, G. S. \& Chen, Y. H. (2011). Mr. risk! Please trust me: Trust antecedents that increase online consumer purchase intention. Journal of Internet Banking and Commerce, 16(3), $1-23$.

\section{Aim and Scope}

\section{Extended Abstract}

Today, electronic commerce is widely used by consumers. Depending on the technological changes in electronic commerce, it has become easier for consumers to access the internet. In addition, consumers prefer mobile usage for electronic commerce. This may lead to rapid information sharing and individual guidance. Consumers realize the products they buy through 
electronic commerce with the help of websites. In addition, consumers can easily access and obtain products/services from different sites through their websites. Consumers, spending time on the web and social networking sites (such as sharing information with friends, being followed in virtual environments, shopping from websites that can be both a seller and a customer at the same time) affect their product purchases. As a result, these and similar factors can affect consumers' perceived online benefit levels, online risks, trust in websites, and the value of websites in the eyes of consumers.

Today, the intense operation of online marketing can direct consumers to these markets at the point of purchasing ready-made clothing products. In line with the research purpose, on the websites where consumers buy ready-made clothing products; three different models have been created that explain the relationships of online benefit, risk, trust, and value. In the first model, the moderating effect of online risk on the effect of online benefit on trust is investigated. In the second model, the effect of online benefit and risk on the value of the site in the eyes of the consumer was investigated. The third model examines the mediating effects of trust in the impact of online benefit and risk on the value of the site. In the research, these relationships were evaluated within the scope of trust theory and the results were interpreted as a whole.

Considering the effects of today's Covid-19 epidemic, the importance of electronic commerce carried out on websites, apart from face-to-face commerce, is increasing day by day. In particular, consumers can easily choose between the ready-to-wear products they will buy by examining the alternatives on the websites. Consumers can develop various value perceptions and feelings of trust towards the sites in their shopping. This shows that online benefits and risks can have significant impacts on product shopping from sites. Consumers' perceptions of online benefits and risks for websites may be affected by the general appearance of the site (such as ease of use, information content, color and advertising content), the ready-made clothing products they purchase, the marketing of the product, and the applications such as discounts and gifts related to the product. These variables may affect the consumer's trust in the website in general and the value of the site for the consumer.

\section{Methods}

The research was carried out with the snowball sampling method. In the literature, it is stated that in snowball sampling, random selection of the sample can make the application difficult and can be easily supported by sampling. It is also emphasized in the literature that snowball sampling can be a useful methodological method in exploratory, qualitative and descriptive research, especially in studies where the number of participants is low and a high level of trust is needed (Baltar and Brunet, 2012: 60). The use of other individuals to reach the sample in snowball sampling provides an important source of information in research. It is also important that individuals have access to and knowledge about the living space of the sample as a result of their past or present situations (Biernacki and Waldorf, 1981: 152). In the research, intermediaries were used to provide easy access to the sample and to have information about the living space of the individuals. In this respect, the advantages of the snowball sampling method were utilized.

Considering the disadvantages in the research, individuals with a high probability of purchasing ready-made clothing products from the internet were included in the application with the snowball sampling method. While conducting the research, it was aimed to provide access to an average of 1500 consumers by keeping the sample size large. For this purpose, taking into account the snowball sampling method, 45 people were accessed at the first stage and an electronic questionnaire was sent. Later, an average of 500 more consumers was accessed through these consumers. A total of 342 people from these consumers, who were accessed, participated in the survey. The data of the study were carried out by applying an electronic questionnaire method to 342 consumers living in the Buca district of İzmir province in Turkey in 2019. In the study, 34 consumers stated that they did not purchase products from websites via the internet. For this reason, the hypothesis models of the research were tested by considering the answers given by 308 consumers. Krejcie and Morgan (1970: 608) stated in their research that 306 people were included in the sample for a population of 1500 people on average. This situation reveals that the analysis made 
with the answers given by 308 consumers has sufficient sampling. Since the websites were examined in the applied study, it was thought that obtaining the study data electronically would yield more rational results. AMOS and SPSS package programs were used in the research analysis. The results of the study's findings and analysis are examined in detail below.

\section{Findings and Conclusion}

Today, companies market their products to consumers with different or similar advertising strategies in ready-made clothing products that change, develop and diversify rapidly. Firms/brands can use their websites or different sites while marketing these products. In this respect, different advertising tools can direct consumers to these products. According to the data obtained from the results of the research, consumers stated that they shop from the websites of trendyol, lcw, other sites, hepsiburada, koton, defacto, gitgidiyor, boyner, mavijeans, collezione, alibaba. The advertising tools that consumers are affected by when choosing these websites are listed as individuals around them, internet ads, television ads, magazine ads and newspaper ads, respectively.

When the research results are evaluated in terms of trust theory; It shows that the perceived benefit of consumers in online product orders contributes significantly to their feelings of trust. In the research, it has been concluded that the risks perceived by consumers in online product shopping reduce their feelings of trust. In the research, it has been seen that the trust in the site in the theoretical framework has important contributions to the value of the site in the eyes of the consumer. These results show that the online benefit, risk and value of the site have significant effects on consumers' purchase of ready-made clothing products from websites in terms of trust theory. These results show that the variables of online benefit, online risk, trust in the site and the value of the site in terms of consumers, which have not been investigated much in the literature together with the theory of trust, may have important contributions to the theory of trust.

Considering the research results in general; Online risks have a moderating effect on the effect of consumers' perceptions of online benefits towards web sites on their trust in the site. The online benefits perceived by consumers from the sites they shop from have led to an increase in the value of the site in the eyes of consumers. On the other hand, the online risks perceived by the consumers from the sites they shop from caused a decrease in the value of the site in the eyes of the consumers. In the research, the online benefits that consumers perceive from the sites they shop from have increased their trust in the site. The online risks perceived by the consumers from the sites they shop from caused a decrease in trust in the site. In the research, the mediating role of trust in the site has been determined in the effect of online risks perceived by consumers from the sites they shop from on the value of the site. It has been observed that trust in the site has a partial mediating role in the effect of online benefits perceived by consumers from the sites they shop from on the value of the site. Finally, consumers' trust in the sites they shop has contributed to the increase in the value of the site in the eyes of the consumer.

In the research, it has been observed that online risk perceptions have a moderating effect on the impact of consumers' online benefits on their trust in the site. It has been observed that as the effect of online benefit level on trust on the site increases, the regulatory effect of online risk also increases. When evaluated in terms of the intermediary relationship, trust in the site had a full mediator effect on the impact of online risks on the value of the site. It has been observed that there is a partial mediator effect of trust on the site in the effect of online benefit on the value of the site. These results show that in terms of the value of the site, the perception of benefit, and risk, the risk perception is more effective in the full mediation of the trust variable to the site. This situation also reveals that the trust mechanism is very important in the effect of consumers' risk perceptions on the value of the site. When the results are evaluated in general, consumers who buy ready-made clothing products from websites find online shopping useful, do not perceive online shopping as risky, trust the site they shop from, and shopping sites for consumers can be valuable. 